\title{
Analysis of the RES Potential in Accordance with the Energy Policy of the European Union
}

\author{
Tomasz Jałowiec (D) and Henryk Wojtaszek *(D) \\ Management and Command Faculty, Institute of Management, War Studies University, 00-910 Warsaw, Poland; \\ t.jalowiec@akademia.mil.pl \\ * Correspondence: h.wojtaszek@akademia.mil.pl
}

check for updates

Citation: Jałowiec, T.; Wojtaszek, H. Analysis of the RES Potential in Accordance with the Energy Policy of the European Union. Energies 2021, 14, 6030. https://doi.org/10.3390/ en14196030

Academic Editor: Dimitrios Katsaprakakis

Received: 11 August 2021

Accepted: 13 September 2021

Published: 22 September 2021

Publisher's Note: MDPI stays neutral with regard to jurisdictional claims in published maps and institutional affiliations.

Copyright: (c) 2021 by the authors. Licensee MDPI, Basel, Switzerland. This article is an open access article distributed under the terms and conditions of the Creative Commons Attribution (CC BY) license (https:/ / creativecommons.org/licenses/by/ $4.0 /)$.

\begin{abstract}
There is a need to reduce carbon-based energy and replace it with clean energy in order to counteract the negative effects of climate change. The increase in renewable energy sources may result in savings and the increasing cost of maintaining carbon-based energy. Worldwide involvement is required. The fulfillment of conditions by individual states does not solve the problem. The COVID-19 pandemic has slowed economic growth. It turns out that economic growth is not always associated with increased investments in RES (existing or emerging new clean energy points). We have a new epidemiological threat-Delta-which could become large. This will not improve the situation. Germany is an exemplary country for benchmarking in the field of renewable energy. The worrying fact is that Poland, despite economic growth, does not achieve an even growth in RES. Each of us is required to be involved, to be open to innovation and to act in accordance with the energy policy of the European Union. Basic management functions (planning, organizing, motivating and controlling) are also essential. Failure to meet the demands of the energy policy should be thoroughly verified and consequences should be drawn in order to involve the whole world. The authors thoroughly analyzed many factors that have a significant impact on the success in stopping climate change and increasing RES. With the increase in energy demand, renewable energy is introduced to a greater extent. Additionally, coal energy will be more expensive to maintain. The more RES, the more expensive the energy obtained from mine sources. The investment is an opportunity to meet the demands of RES, but investors are currently only interested in investing in renewable energy in highly developed countries. The decision-making process regarding the implementation of renewable energy sources not only consists in a radical decision to introduce changes, but also in the fulfillment of a number of assumptions regarding the energy policy controlled by the authorities of a given state as part of this action. There is a risk (fear) in underdeveloped countries that they will not be able to finalize this project, either due to the lack of investor interest or the lack of real opportunities due to the failure to meet the guidelines of the energy policy of a given country. It is advisable that state governments facilitate the process as much as possible so that even less developed countries could take advantage of this postulate.
\end{abstract}

Keywords: energy; renewable energy; climate change; energy policy

\section{Introduction}

The oriented need for energy results from the progressive development of economic growth. The pandemic slightly slowed down economic growth. People are knowledgeable about energy and there is a need to limit carbon-based energy.

Carbon-based energy has a negative impact on the environment, human life and health. The solution is renewable energy sources (RES). The growing importance of RES in the world fuel and energy balance may indicate savings when energy resources [1] are consumed and the condition of the environment is improved by: reducing the emission of pollutants into the air and water, as well as reducing the waste produced. Any activities 
aimed at the development of renewable energy sources are becoming the main assumption of the energy policy of many countries around the world [2,3].

Currently, negative effects are observed due to the progressive climate change [4]. Many research reports and experts indicate climate change as the leading human and environmental problem of the 21st century $[5,6]$. It seems clear that the impact of climate change on clean energy and investment varies significantly between countries with different levels of clean energy investment $[4,7,8]$.

The proper structure of the energy transformation allows for the operation of even the smallest link (each of us). Social responsibility is essential—an individual contribution to sustainable development: building the future using the achievements of the past, but free from its negative effects [9].

Innovation is considered as new creative teams are meeting the desired effect $[5,10]$.

Figure 1 below presents the dimensions and determinants of the energy transformation in Poland.

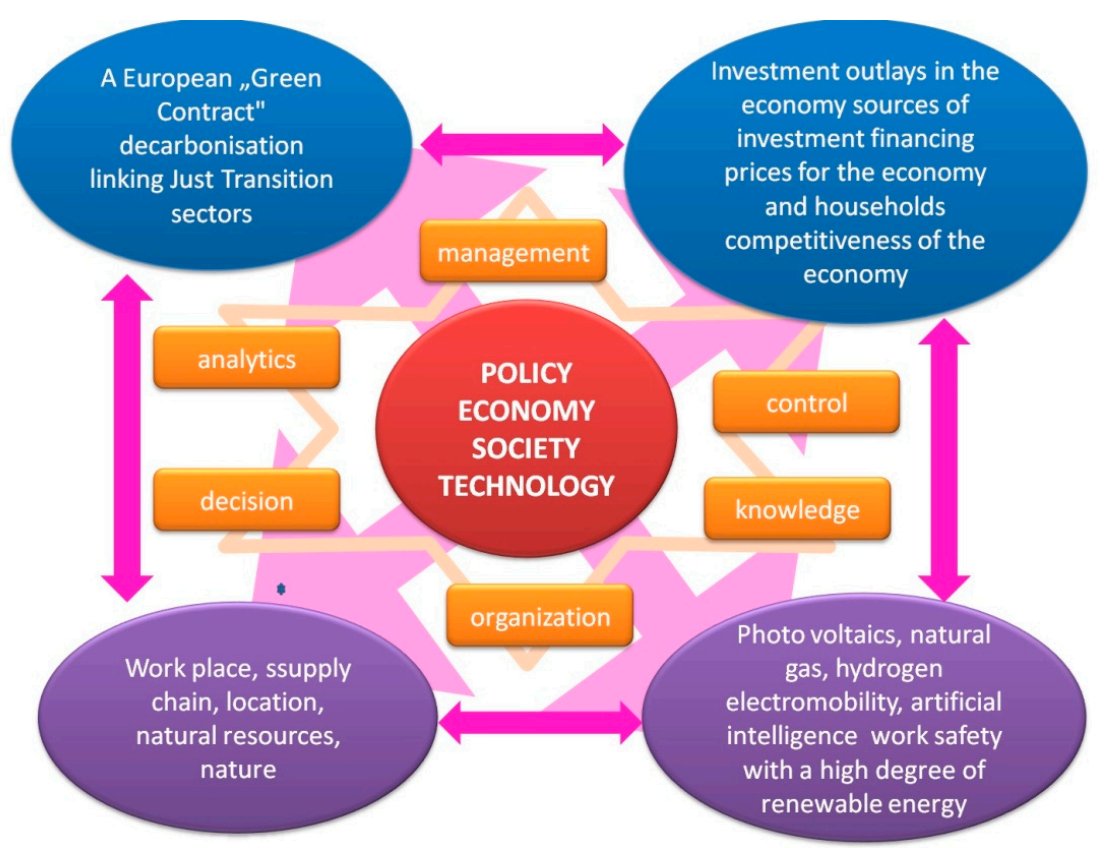

Figure 1. Dimensions and determinants of the energy transformation in Poland [9-11].

The planned changes consist in establishing new jobs, building the electric power industry as a closed circuit [11], increasing outlays for the reconstruction of the energy mix and obtaining RES by 2030 in the amount of $40 \%$ and by 2040 to $68 \%$. It is planned to decrease the average wholesale electricity price by 2030 and 2050 (by $5 \%$ and $26 \%$, respectively) and to reduce $\mathrm{CO}_{2}$ emissions by 2030 and 2050, compared to 2005 , by $56 \%$ and $95 \%$.

Figure 2 below presents the dimensions and assumptions of the 2040 energy policy. 


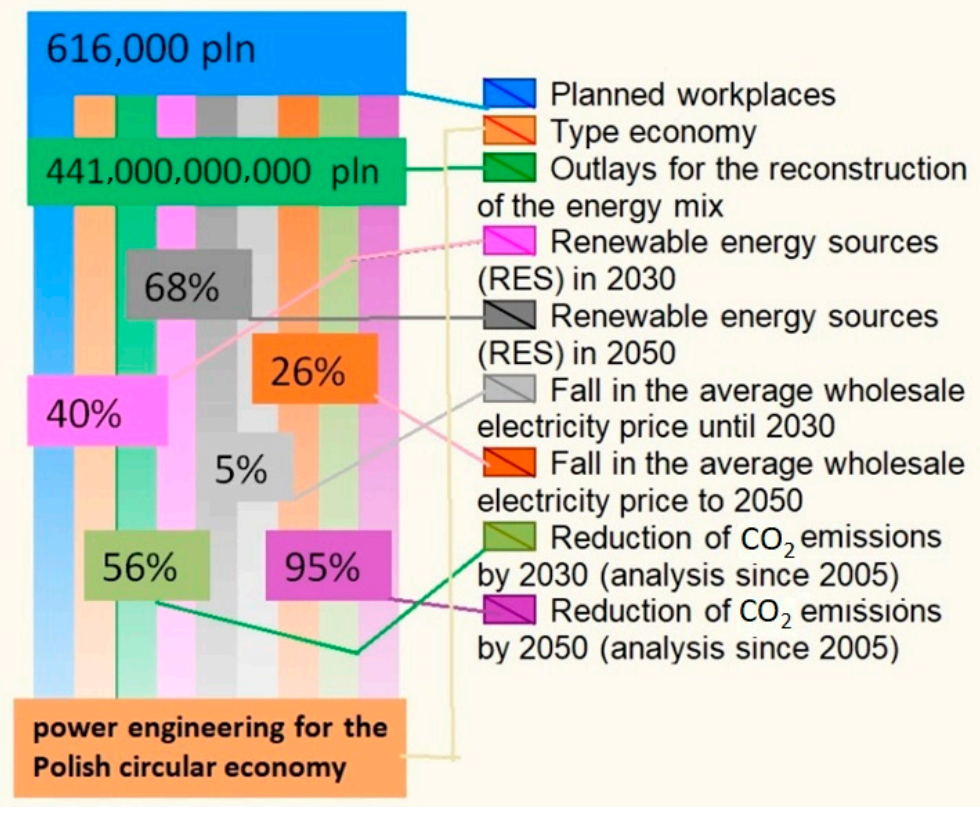

Figure 2. Dimensions and assumptions of the energy policy 2040 [9-11].

Poland should learn about the energy transformation from Germany [12] on the basis of the benchmarking experience [13-16]. The dimensions and determinants of the energy transformation in Poland indicate its essential elements and are related to any decision-making in energy policy as well as analysis, decisions, management, control and knowledge [12,17]. The reconstruction of the Polish economy is of particular importance in the era of the COVID-19 pandemic and a variant of the next Delta pandemic [18].

It becomes crucial to make decisions aimed at increasing jobs. There have been global social changes that have already occurred [19] as a result of the digital revolution and the global technological level already achieved in the field of RES generation sources, energy storage systems and management in the processes of its use.

The actions resulting from the COVID-19 pandemic and those carried out to stop the negative impact on the entire global economy in order to avoid its further collapse are as follows. The inevitable consequence of the pandemic was a reduction in production (demand and supply) and even a standstill. Long-term effects reduce globalization, increase the indebtedness of economies and reduce the gap between the most developed economies. A positive aspect is the acceleration of the development of the digital economy, including the services market [20].

The pandemic [21] has caused major restrictions on social and economic activity and barriers to movement around the world. Consumption of goods, apart from the basic ones necessary for everyday functioning, has decreased dramatically. Potentially, places where services other than food were provided along the entire chain of operations, the functioning of the entire process was disturbed. We are aware of this, that the proper functioning of each enterprise depends on many contractors and factors. The GDP (Gross Domestic Product) situation was uncertain throughout the world economy. Even in markets recognized as dynamic-China-also experienced the first ever decline in GDP. It is planned to increase by the end of 2021, even to $6 \%$ [22].

The negative phenomenon has hit the financial markets. Losses concern the whole world towards the financial and currency markets (up to $20 \%$ of the value) [23].

International cooperation will be of key importance in reducing the collapse of the global economy.

The disturbing information is the fact that Central European countries ended 2020 without economic growth.

The decline in GDP due to the pandemic is presented in Figure 3. 


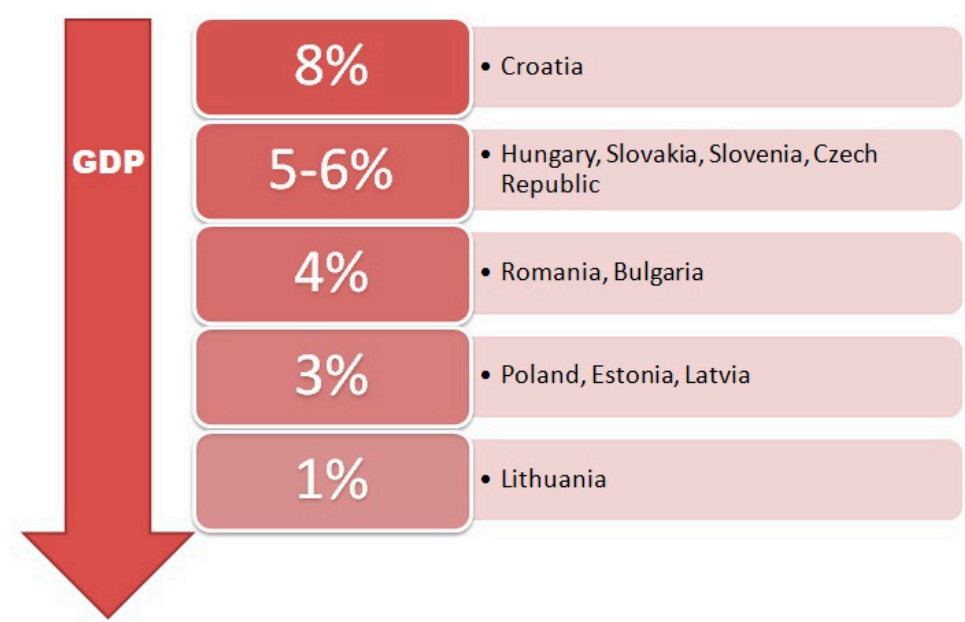

Figure 3. GDP decline due to the pandemic by country [20-23].

The slowdown in the economy mainly affected the tourism industry-one of the largest economies in southern Europe.

Thanks to radical measures (on health care, benefits, subsidies, support for enterprises), it is estimated that even three times the negative effects of the recession around the world have been stopped. The relation to GDP in 2020 was the smallest in Romania-it amounted to $2.2 \%$, then comparatively, Bulgaria and Croatia, respectively, less than and over $5 \%$, and Lithuania, Poland and Latvia (6.5\%, almost $8 \%$ and $9 \%$, respectively).

Despite involvement in public programs, it was not possible to avoid progressive unemployment. In all Central European countries, except Poland, in 2020, a significant increase in unemployment was noticed, which is presented in Figure 4.

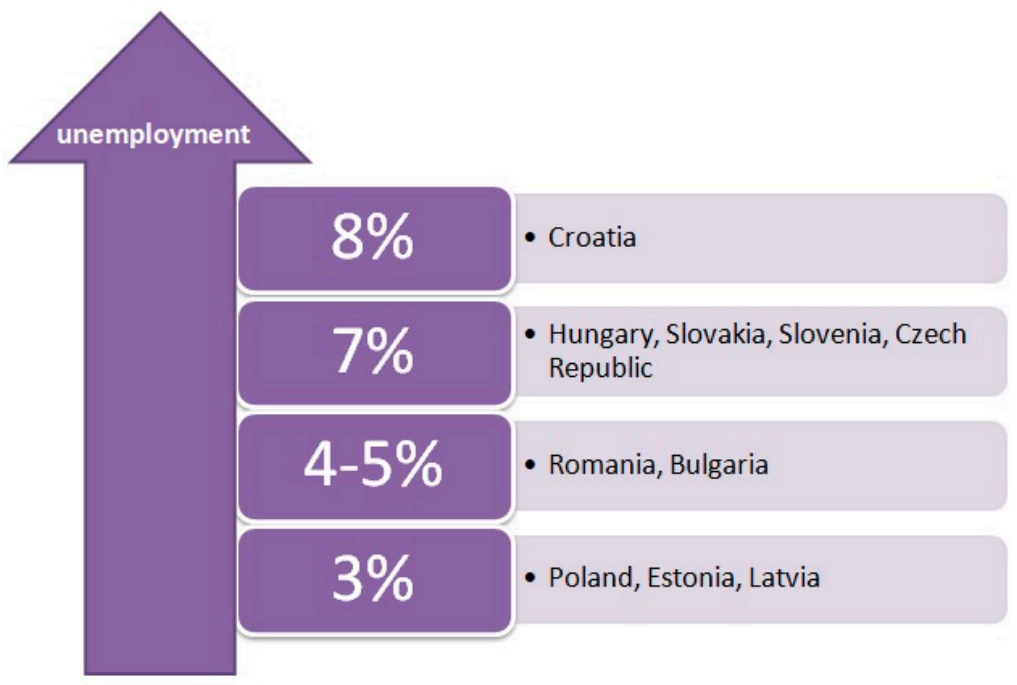

Figure 4. The unemployment rate in 2020 [20-23].

However, the increase in unemployment was irregular when analyzed by age groups and gender. The situation of especially young people has changed, as they are the most active job seekers and the most unemployed in the region of Central Europe (Croatia, Slovakia, Estonia). The dominant increase in unemployment in the labor market concerned mostly women ( $85 \%$ work in services).

The position of the long-term unemployed is not changing for the better, as entrepreneurs will prioritize the re-admission of dismissed workers, and only then the employment of new ones. 
It can be indicated that activation does not provide a clear impact on the improvement of the situation on the labor market. This is due to the development of the employment structure during the pandemic. Mainly, there is a reduction in employment of low-skilled workers and an increase in the demand for professionals in the areas of high technology. The long-term unemployed may be at risk of poverty and social exclusion.

It turns out that the COVID-19 pandemic affects inflation in different ways. As a rule, in times of recession, it is reasonable to expect inflation to fall as demand in the economy slows down. The simultaneous evolution of supply and demand leads to an evolution towards increased inflation, disinflation and also deflation.

The following Figure 5 shows the phenomena resulting from the evolution of supply and demand. In 2020, among the countries of Central Europe, we suffered from all these phenomena: inflation at the level of approx. 3-4\% in Poland, the Czech Republic and Slovakia, which was also the highest level of inflation in the entire EU; disinflation bringing inflation down to the level of approx. 1-2\% in Romania, Slovakia, Bulgaria and Lithuania; disinflation bringing inflation down to around $0 \%$ in Latvia and Croatia and deflation of around $-0.5 \%$ in Slovenia and Estonia (Figure 5).

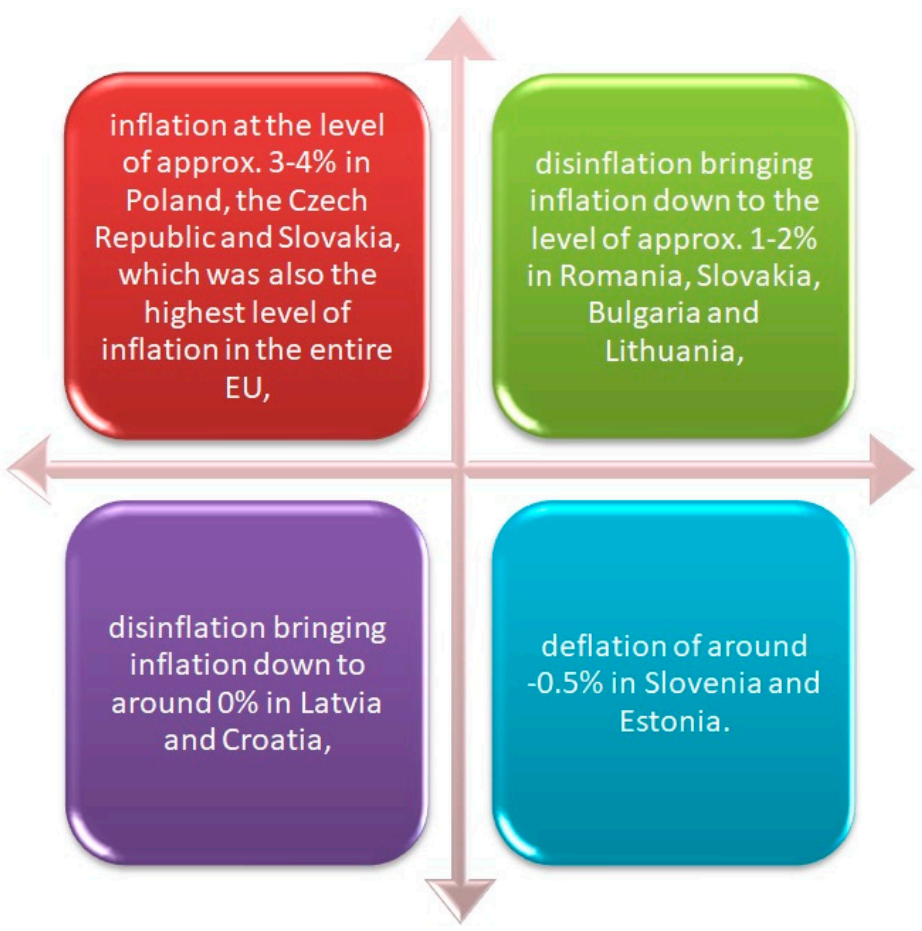

Figure 5. Phenomena as a result of the evolution of supply and demand [22,23].

The authors emphasize that the COVID-19 pandemic was a serious shock to the economies of Central Europe. The analysis of the real GDP growth rate, unemployment rate and inflation resulted in a change in the economic situation of these countries in 2020.

Economies in Europe decreased by almost 5\% in comparison with 2019 to 2020. Unemployment has risen. Inflation was $2.5 \%$ and $1 \%$ lower in 2019 and 2020, respectively, as shown in Figure 6.

The latest IMF (International Monetary Fund) forecasts for 2021 indicate a recovery in all analyzed economies. Making up for the losses after the recession of 2020 relies on expansionary fiscal policy. Governments are advised to grant public aid to citizens and businesses most affected by the crisis. The pandemic hit the most vulnerable social groups (young, unemployed). The danger is that with a recovery, the most vulnerable groups in society will be given a job with considerable delay. 


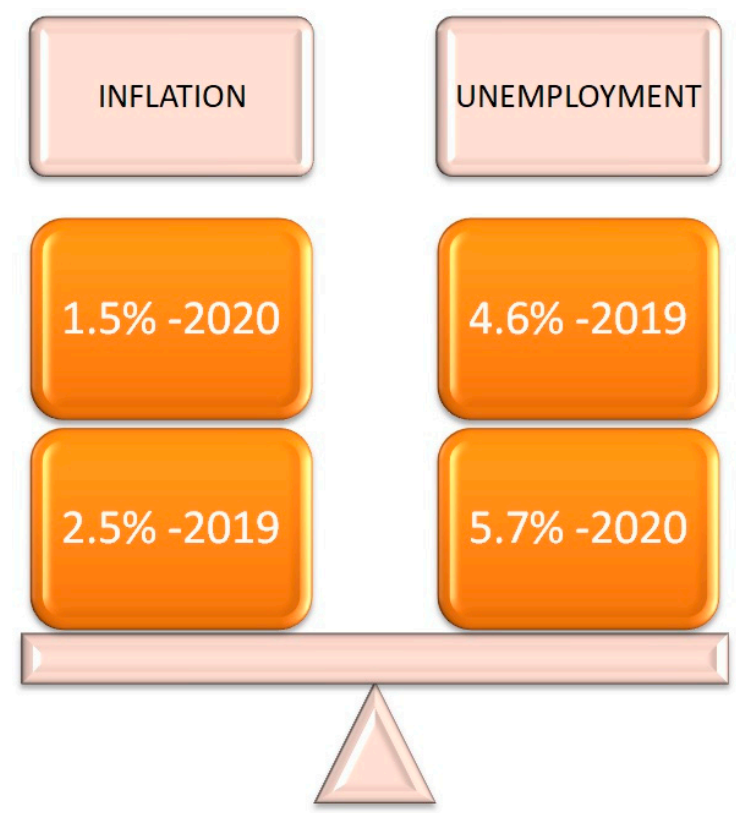

Figure 6. Comparison of inflation and unemployment 2019-2020 [24,25].

Long-term actions based on health care, education and actions aimed at ending climate change become key.

In the special report of 7 July 2021, there is information that Poland is recovering from the pandemic. Economists say they expect a significant improvement that will result in double inflation [24]. The pandemic has slowed economic growth [25].

\section{Materials and Methods}

\subsection{Energy Policy of the European Union}

The countries of the European Union, together with other countries and organizations in the world, implement the United Nations Framework Convention [26] on Climate Change. The European Union is a key player in climate policy [27]. It has become a world leader and creator of comprehensive regulatory standards in the field of climate protection and reduction of $\mathrm{CO}_{2}$ emissions [28]. The EU Emissions Trading Scheme is the first and international trading scheme for $\mathrm{CO}_{2}$ emissions [29].

The system is a key element of the European Union's climate policy and the basic tool for reducing greenhouse gas emissions [30]. The energy and climate package focused on three strategic goals: reducing greenhouse gas emissions, promoting the use of energy from renewable energy sources and increasing the energy efficiency of the European Union [31]. This package became the starting point for new reduction targets in the following years [32]. The leaders of the European Union decided, on a global scale, the climate and energy policy until 2030. They obligated the member states to reduce emissions by 2030 in total by at least $40 \%$ compared to 1990 .

In addition, the European Council approved four goals for the entire European Union by 2030: reducing greenhouse gas emissions by at least $55 \%$ compared to 1990 emissions; at least 32\% share of renewable sources in gross final energy consumption; an increase in energy efficiency by $32.5 \%$ and the completion of the EU internal energy market.

The presentation of the "Clean Energy for all Europeans" [33] package marks the role of the Energy Union in the global and comprehensive transformation towards a low-carbon economy to mitigate climate change. The operationalization of the EU's climate and energy goals is required, affecting the construction of a single EU energy market [34]. The Winter Package initiated a reform of the Energy Union management system, an amendment to the RES Directive and the Energy and Market Efficiency Directive. The key implementing act for the Polish electricity sector was the legal regulation limiting the use of support in the form of the capacity market for installations where the level of carbon dioxide emissions 
exceeds $550 \mathrm{~g} \mathrm{CO}_{2} / \mathrm{kWh}$. The European Green Deal [35] was presented as a European growth strategy aimed at transforming the European Union into a fair and prosperous society. The strategy aims to minimize net greenhouse gas emissions to zero [36]. The plan is that the European Union is to be the first climate neutral continent in 2050. The European Commission has proposed a European Climate Law [37] that will perpetuate the goal and provide the EU with the means to achieve it. The Green Deal is a challenge for Poland. Poland is dependent on the Polish power sector and traditional fuel. A fair transition is key, creating a factor and securing an uneven distribution of costs. The costs of transformation will not be borne by the countries operating on coal, which have fewer financial possibilities than the richer EU Member States, which can afford earlier declarations of climate neutrality. Member States will update their national energy and climate plans in 2023, meeting new and more ambitious climate goals.

Since Poland's accession to the EU, the energy sector has to adjust to changes in the community energy market. They have evaluated the organizational structures of energy entities, and market regulations have been introduced for the operation of enterprises. Development should be consistent with the European energy and climate policy and the strategy for the development of renewable energy sources. Capital-intensive modernizations are carried out and innovative technologies are becoming more environmentally friendly. As a result, the power sector companies with the Treasury share significantly minimized $\mathrm{CO}_{2}$ emissions. The implementation of higher climate goals [38], increasing the prices of $\mathrm{CO}_{2}$ emissions by reducing support for coal-based energy after 2025 show other key changes in the power sector, aimed at strengthening the competitiveness of the Polish economy. The transformation of the sector should take into account the European climate policy and be oriented towards low- and zero-emission sources of electricity generation.

\subsection{Poland's Energy Policy until 2040}

The operation of the resolution of 2 February 2021 heralded the life of the Energy Policy until 2040 and the scope of the energy transformation. A low-emission energy system is being achieved by radical decisions, changes and adaptation of appropriate tools in this regard.

The implementation of the Paris Agreement [39] takes into account the scale of challenges related to the adaptation of the national economy to EU regulations related to the climate and energy goals for 2030 and the European Green Deal, the economic recovery plan after the COVID-19 pandemic and the pursuit of climate neutrality. The policy is aimed at modernizing the energy sector through zero-emission development and creating innovation, aiming at systematic economic development, increasing efficiency and competitiveness. Three pillars were identified: Just Transition, Zero-emission energy system and good air quality. They are the basis for specific objectives along with the activities necessary to achieve them through strategic activities. Poland strives to secure the demand for power with its own resources. Domestic coal resources will remain an important element of Poland's energy security. Renewable sources play a key role, where their share in the structure of domestic net electricity consumption should be no less than $32 \%$ in 2030. This creates the possibility of the development of photovoltaics and offshore wind farms. The implementation of the strategy will stimulate the improvement of air quality, environmental protection and climate protection. The energy transformation requires the involvement of many entities and significant investment outlays. For social, economic and environmental reasons, the restructuring of coal regions will be done in such a way as to strengthen the economy and contribute to the well-being of future generations. The key solutions will be included in the national and territorial just transition plans. The implementation of the assumptions of PEP2040 (Poland's Energy Policy until 2040) will not be possible without the key involvement of companies with the Treasury in the transformation of the Polish power sector. The large-scale investments planned by the sector in low-emission sources of electricity and heat and intelligent electricity infrastructure will create a solid reduction in emissions from the Polish energy mix, ensuring not only 
the reduction of the negative impact on the environment, but also security of supply and acceptable prices of electricity and heat for end users. The companies are already analyzing gas projects aimed at replacing the worn-out coal-fired units in the transitional period. The analyses also include many development projects in line with PEP2040, which concern, inter alia, energy storage technologies, alternative fuels and hydrogen technologies.

Opportunities for breakthrough change should be found in offshore wind energy, which is a relatively stable source of renewable energy. This innovative industry will enable the involvement of local industry and wide international cooperation. The decline in the cost of renewable energy technologies, the digitization of the economy and new technologies will create the conditions for accelerating the transformation of the energy system over the next two decades. The implementation of the EU reduction obligations imposed on Poland is guaranteed by the effective transformation of companies in the electricity sector and their adaptation to the current market challenges. Involvement of all entities-Poland should meet the EU's [40] climate and energy challenges without the need to generate decisions with negative economic effects. Achieving the appropriate goals in a given period is possible through planned actions and gradual implementation of changes.

\subsection{Characteristics of Changes in Electricity}

Considering changes in the profitability of electricity [41] should also take into account changes in the maintenance of already existing equipment and machinery. Depreciation of machines often requires a change in terms of replacement with new parts or the purchase of a completely new device. This increases the costs-this factor is rarely taken into account. The functionality through depreciation is reduced by at least $30 \%$. It is worth noting that these are not new devices as they can be even $40-50$ years old.

An overall energy breakdown is provided in Figure 7 below.

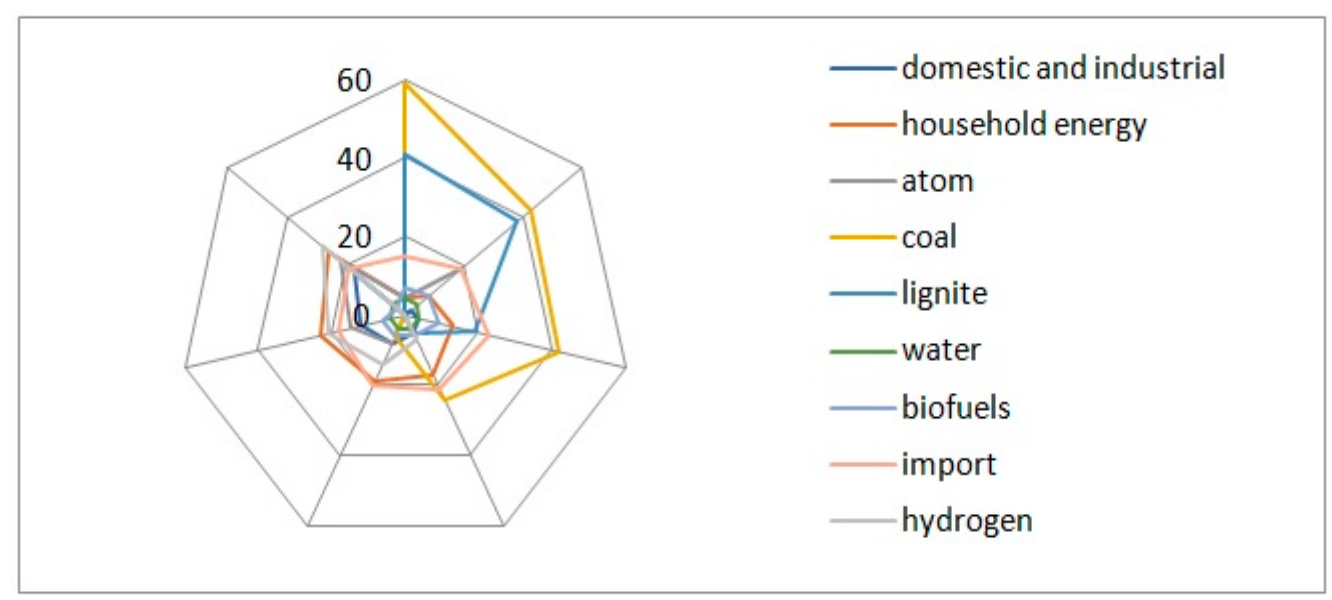

Figure 7. General statement of energy [42].

The highest upward trend was noticed in biofuels from 2025 to 2050, which is steadily and successively growing from smallest to the largest. In total, in CCGT and GT (Gas Turbines), to a small extent (2021-2025), high (2035-2040), medium (2040-2045) and low (2045-2050). We notice a downward trend in lignite and hard coal-from the higher (lower limit) and medium (lower limit) to the lowest, respectively, from 2021 to 2035. A moderate development tendency is visible in Onshore from 2025 to 2050 (it aims to increase from the beginning, increasing by 2.5 or 3 times by the end of 2050. Similarly, hydrogen-only from 2035 to 2050. Imports are insignificant (upper limit) from 2021 by 2050 on average by $0.3 \%$ with an upward trend until 2030 and from 2035 to 2050 with a downward trend (by an average of 1.2 points). From 2040, the atom begins at a small extent, doubled by 2045, and in 2050 is reduced by $1 / 4$ from the previous period. It is estimated that renewable energy will increase up to $40 \%$ by 2030 and $70 \%$ by 2050 . 
Complementing the mix regarding the operation of the system are battery warehouses to be completed by 2050. An additional economic effect may be a decrease in the average wholesale electricity price, which will positively affect the competitiveness of the economy. With the increase in the share of low- and zero-emission sources, the energy transformation in the long term will contribute to the reduction of electricity generation costs which are caused by high prices of $\mathrm{CO}_{2}$ emission allowances [43].

In the latest report published on 12 August 2021 [44], indicating the share of renewable energy sources, it is possible to indicate a $15 \%$ share of renewable energy in all electricity.

Figure 8 shows the production of electricity from RES in GWh in Poland and the structure of RES capacity in 2021 in Poland is presented in Figure 9.

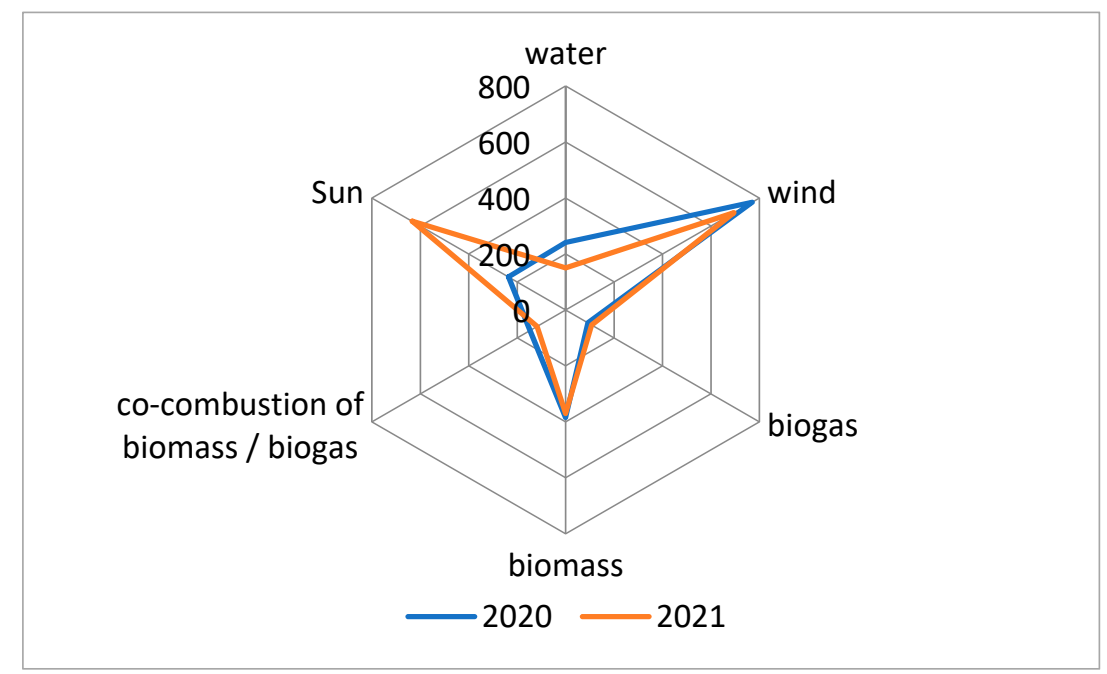

Figure 8. Electricity production from RES (GWh) in Poland [45].

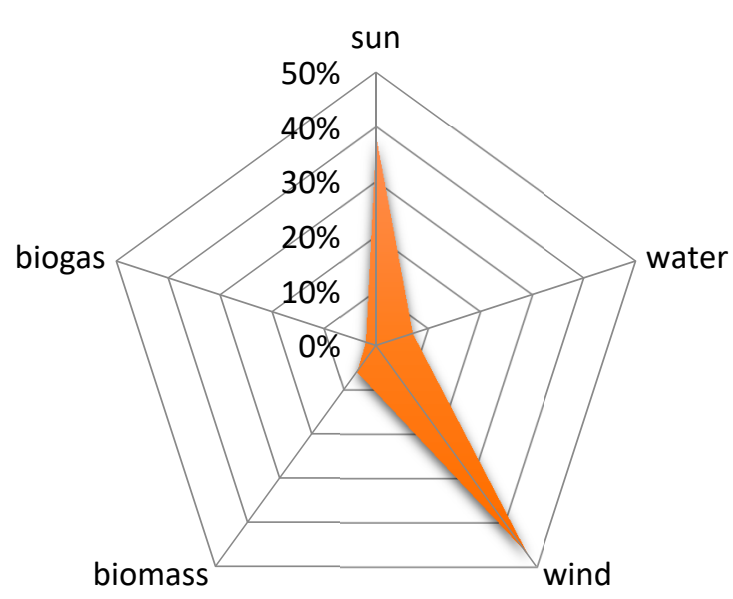

Figure 9. The structure of RES capacity in 2021 in Poland [46].

Data from June 2021 allow us to conclude that the largest part of the structure of the installed RES is wind, which is less than 50\% later; the sun-also less than $40 \%$.

Among new RES installations, photovoltaics account for $99 \%$.

Figure 10 below presents PPS operation-generation of wind and photovoltaic sources. 


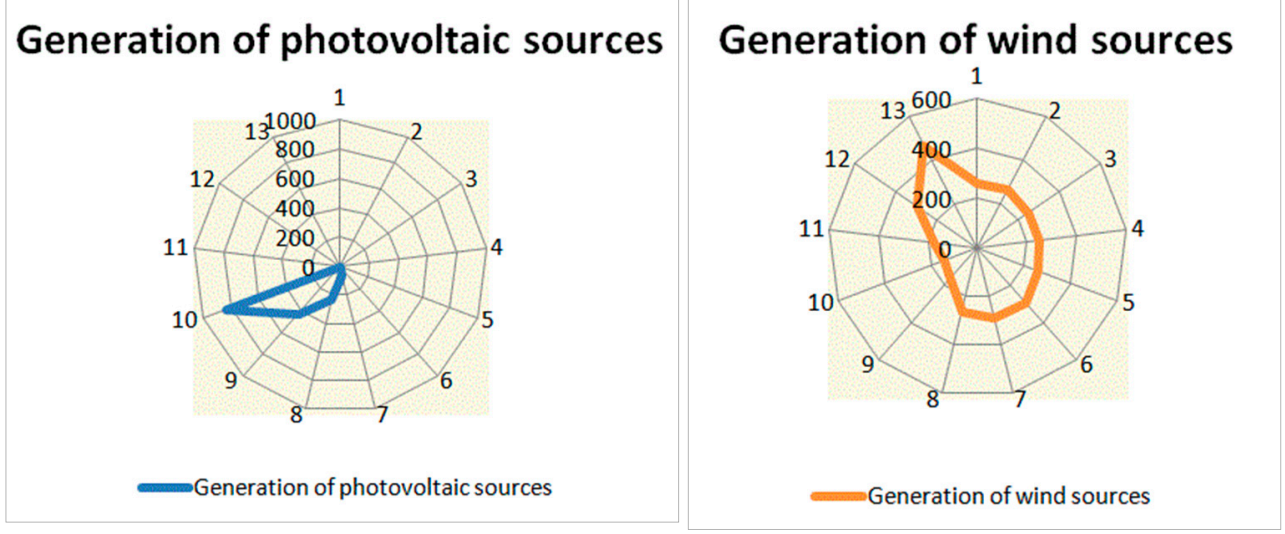

Figure 10. KSE operation-generation of wind and photovoltaic sources [47].

The percentage share in the national electricity production of individual groups of power plants by fuel type in 2019 is presented in Figure 11, when in 2019, the share of energy generated by hard coal-fired commercial power plants was the largest (almost 50\%). Lignite-fired utility power plants were next $(26.14 \%)$. The next share oscillated around $10 \%$, and these were, successively: wind and other renewable power plants, commercial gas power plants and industrial power plants. The smallest share was that of commercial hydropower plants $(1.55 \%)$.

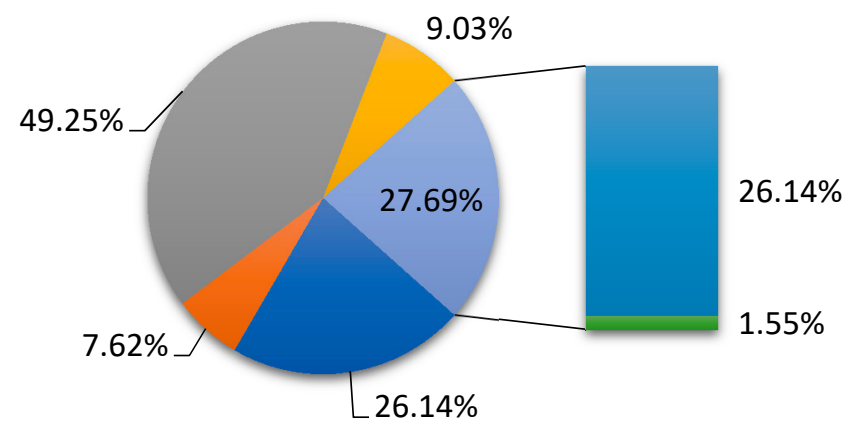

$$
\begin{aligned}
& \text { industrial power plants } \\
& \text { commercial gas power plants } \\
& \text { hard coal-fired commercial power plants } \\
& \text { wind farms and other renewable } \\
& \text { lignite-fired commercial power plants } \\
& \text { commercial hydropower plants }
\end{aligned}
$$

Figure 11. Percentage share in the national electricity production of individual groups of power plants by fuel type in 2019 [48].

\subsection{Directions of the Energy Transformation in Germany}

Although the goals of the country's energy transformation are widely accepted in Germany, the specific course of action is controversial. Appropriate measures, which are part of the energy transition policy, and interactions in the European context, are the subject of a scientific and public debate. The consequences for the price of electricity were actively debated.

Figure 12 below shows electricity generation in Germany. 


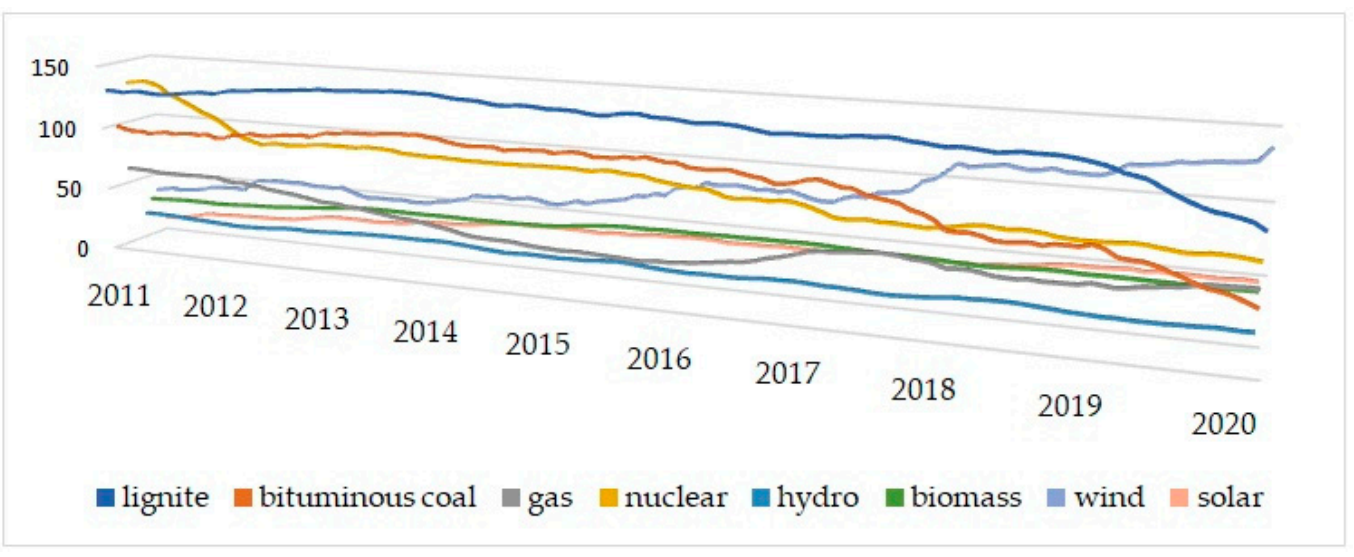

Figure 12. Electricity generation in Germany (TWh) [49].

Electricity production in Germany [50,51] shows the 12-month average data in the figure above (Twh generation). Energy production in Germany shows the 12-month average data in the figure above. Electricity production in Germany is very extensive and consists of nuclear, gas and renewable energy, as well as hard coal and lignite. The production of electricity from coal has a downward trend; this is the result of charges for $\mathrm{CO}_{2}$ emissions to the atmosphere and the decline in renewable energy prices, especially wind and sun. In the period from March 2019 to February 2020, Germany produced 140 (TWh) of electricity; compared to Poland, it is slightly less than the entire annual net electricity consumption.

Figure 13 below presents Energy sources in German electricity production-12-month average .

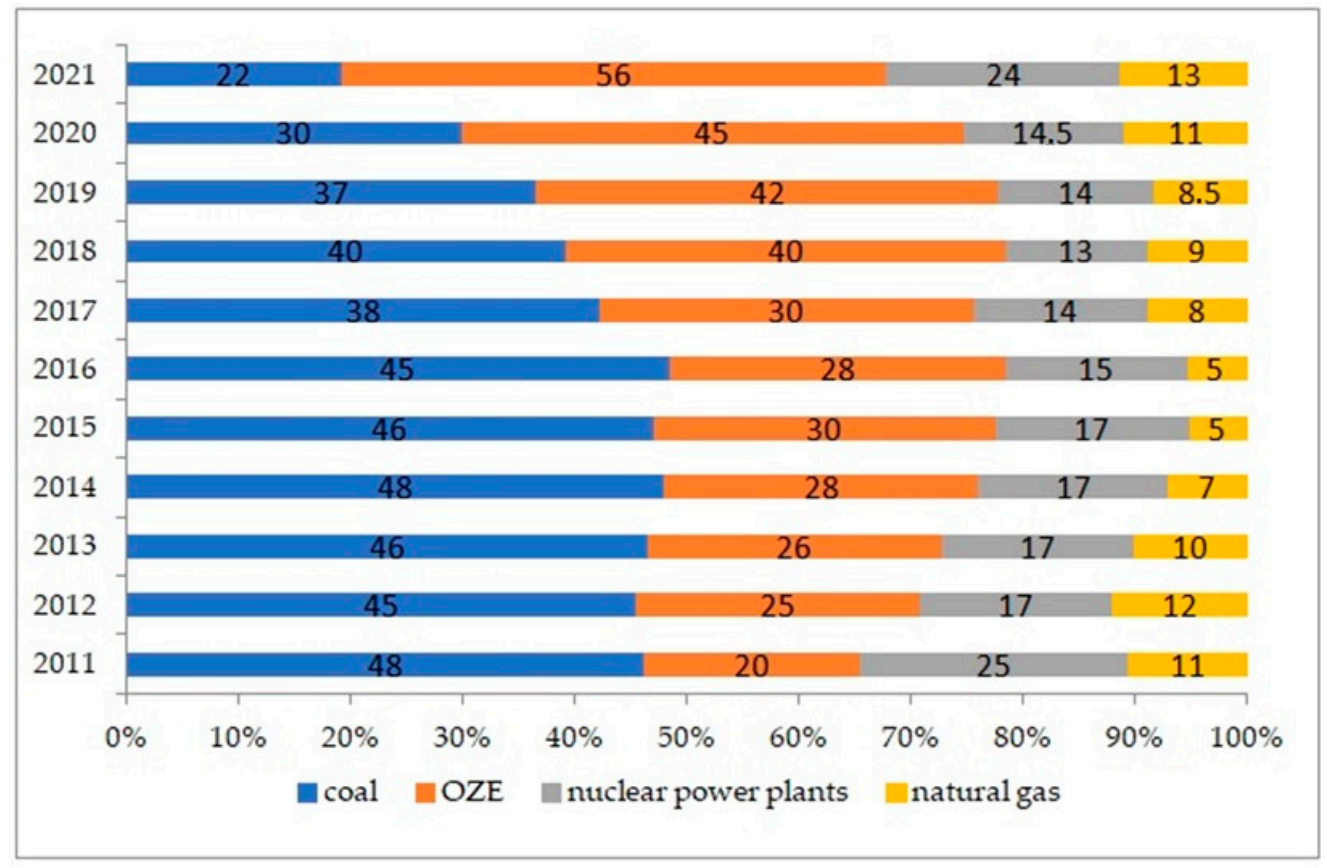

Figure 13. Energy sources in German electricity production-12-month average [52].

Experts say climate change [53] is to some extent inevitable today, due to the high degree of inertia that characterizes climate change [54,55]. Global warming could continue for the next several decades, even if the concentration of carbon dioxide in the atmosphere were stabilized at the current level—by far the highest in our recent history [56].

The share of renewable energy in the electricity mix is growing rapidly, to a level close to $50 \%$. The share of electricity from nuclear power plants is slowly falling. Coal energy maintenance costs are rising. Compared to 1990, Germany reduced its carbon dioxide 
emissions by 25.5 percent (data at the end of 2012). They, therefore, exceeded the Kyoto Protocol target of reducing emissions by 21 percent by the end of 2012. Regardless of what has been achieved so far, Germany intends to go further and reduce emissions by 40 percent by 2020 and $80-95$ percent by 2050 . These goals may seem immensely ambitious, but the industrialized world needs to move much faster in light of the consequences ahead. If we are to meet the objectives of a low-carbon economy of 450 parts per million, we cannot emit more than 1230 billion tons of greenhouse gases. In 2004, greenhouse gas emissions were approximately 50 billion tons; without changing patterns of behavior, we will exhaust the assumed budget after 25 years. This means that from 2030 onwards, global carbon dioxide emissions would have to be zero.

Furthermore, recognizing developing countries' rights to slightly higher emissions (for development reasons) implies a greater responsibility of industrialized nations to reduce emissions. In other words, Germany is faced with the need to cut carbon dioxide emissions by $95 \%$, not by 80 . In 2010, WWF (World Wildlife Fund) asked Germany's Institute for Applied Ecology and the consulting firm Prognos to investigate what action was needed to reduce carbon dioxide emissions by 95 percent without lowering living standards. In short, it turned out that, first of all, it was necessary to significantly increase energy efficiency in order to reduce the demand for energy (including heat), and then switch the energy management to renewable energy sources. The only highly problematic industry is the demanding transport sector for the entire range of solutions-however, the study shows that there are opportunities to reduce emissions from this sector by $83 \%$ by 2050 compared to the current state. The market already offers a range of high-performance technologiesfor example, LED lighting instead of conventional incandescent lamps. Thanks to efficient air conditioning and heating systems, passive houses are able to provide a high level of comfort with low levels of energy consumption. Renewable energy sources (RES) cover an increasing percentage of energy demand. Thanks to renewable energies, Germany saved 146 million tons of carbon dioxide emissions in 2012, of which 101 million tons was in the electricity sector. Additionally, biomass is essentially zero-emission: its emissions correspond roughly to the amount of carbon that the plants used to produce energy have bound. In 2011, the use of biomass in the production of electricity, heat and transport fuels reduced carbon dioxide emissions by approximately 66 million tons [57].

The key factor for Germany to obtain efficiency from renewable energy sources is to reduce energy imports. Germany imports $70 \%$ of the energy it consumes. Renewable energy sources and higher energy efficiency make a significant contribution to reducing imports and thus to increasing Germany's energy security. Transformations on the energy market are a stimulus for the development of innovative environmentally friendly technologies, contribute to the creation of new jobs and help Germany build its position as a country exporting green technologies. Last year, energy production in small installations using renewable energy sources remained at a level similar to 2019-according to the latest ERO report, where the production and sales of energy in 2020 in small RES installations are presented below (Figure 14) [58].

The ratio of the sold energy to the produced energy is, in each case, higher, which may indicate good deposits and good quality of work. The least amount of biomass is produced and sold as energy. Hydropower is marketed and produced to the greatest extent. Three times more (to a greater extent) energy from non-agricultural biogas is sold than produced. Similar, but twice as much the situation applies (radiation energy and solar energy) for energy sales and purchases, respectively. Wind energy has a very similar ratio in terms of production and sales. 


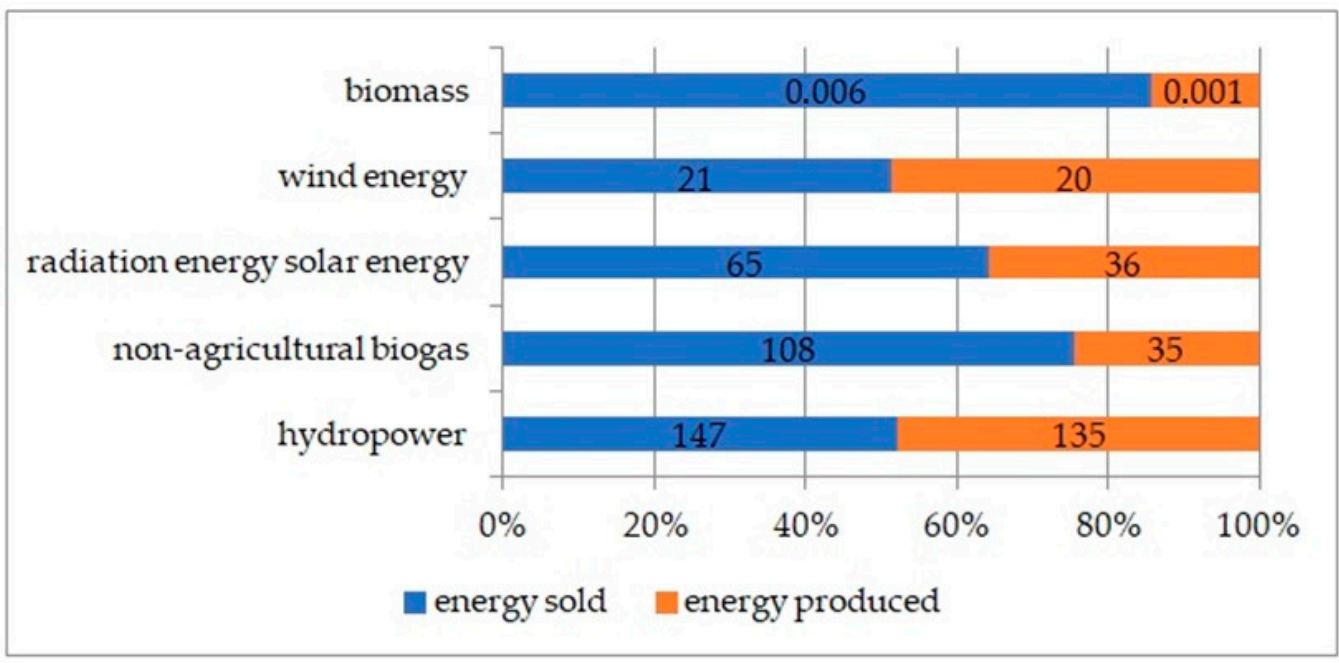

Figure 14. Renewable energy in 2020 (GWh) [59].

RES installations by source (as at the end of 2020) are presented in Figure 15.

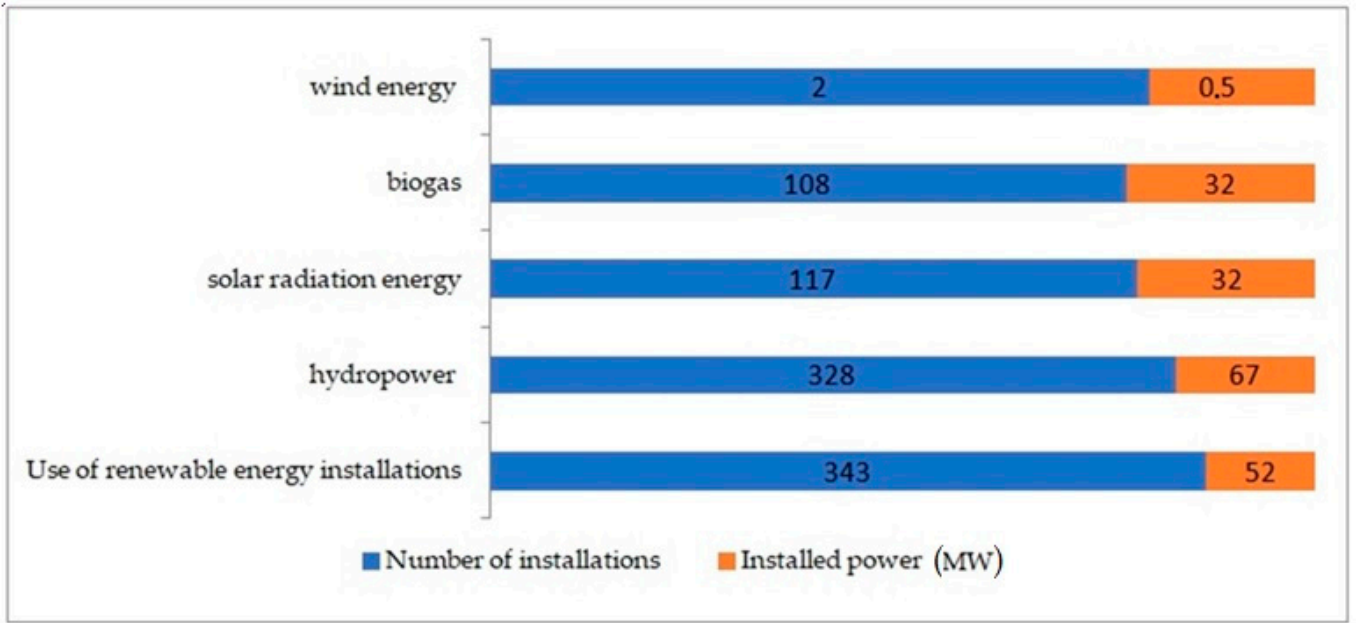

Figure 15. RES installations by source (as of the end of 2020) [60].

The most used installations are 343 (number of installations) with the installed capacity of 52 (MW). The largest installations are implemented successively: hydropower, solar radiation energy, biogas and wind energy. The slightest degree was wind energy (only two installations). The power was similar to the number of installations (shown from the largest to the smallest); the same result is shown for biogas and solar radiation energy-32 (MW).

Hydropower was produced to the greatest extent between 2016 and 2020 (Figure 16). We present (from the largest to the smallest) 2019, 2020, 2018, 2017 and 2016. The energy of solar radiation was greatest in 2020, 2019, 2018, 2016 and 2017-to the same extent. Biogas to the greatest extent was 77 GWh in 2017, very similar in 2020 and 2016, and also very similar in 2019 and 2018 (Figure 17). It is the smallest degree of wind energy compared to the ones indicated in the RES study which was mostly 2019, then 2020, respectively, and the least was 10 GWh in 2018. 


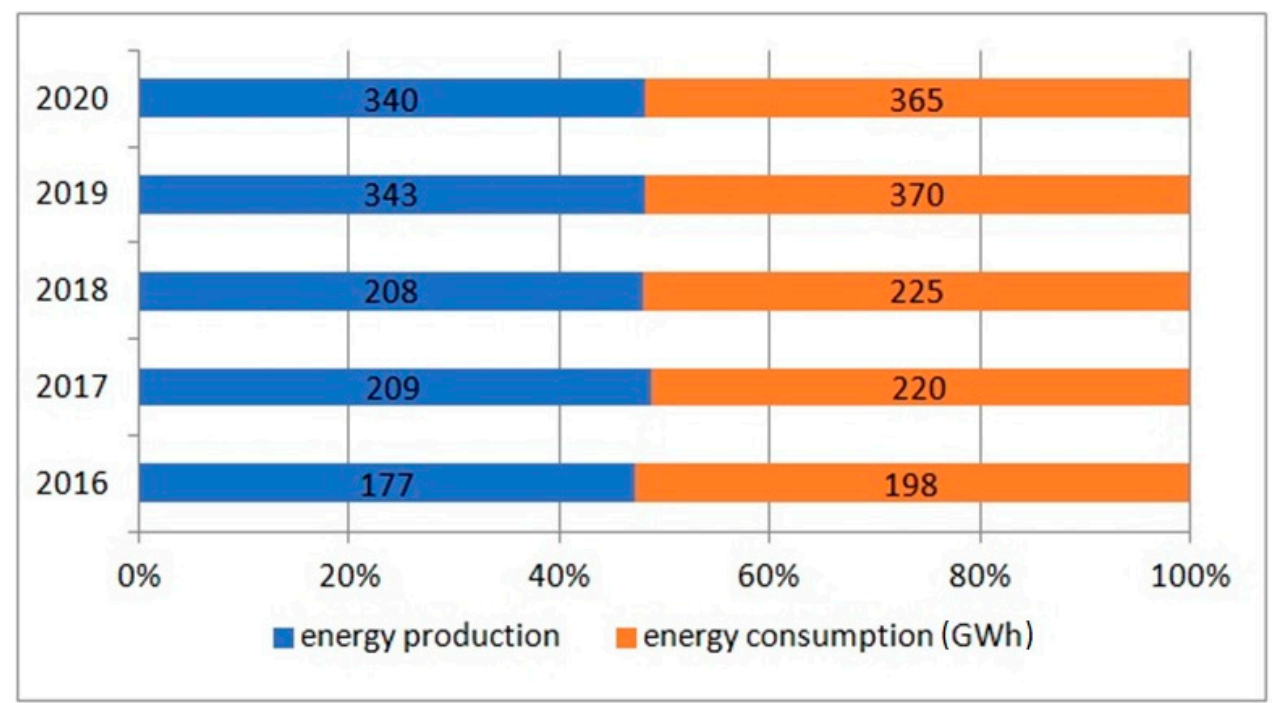

Figure 16. Energy production in small RES installations in 2016-2020 (GWh) [61].

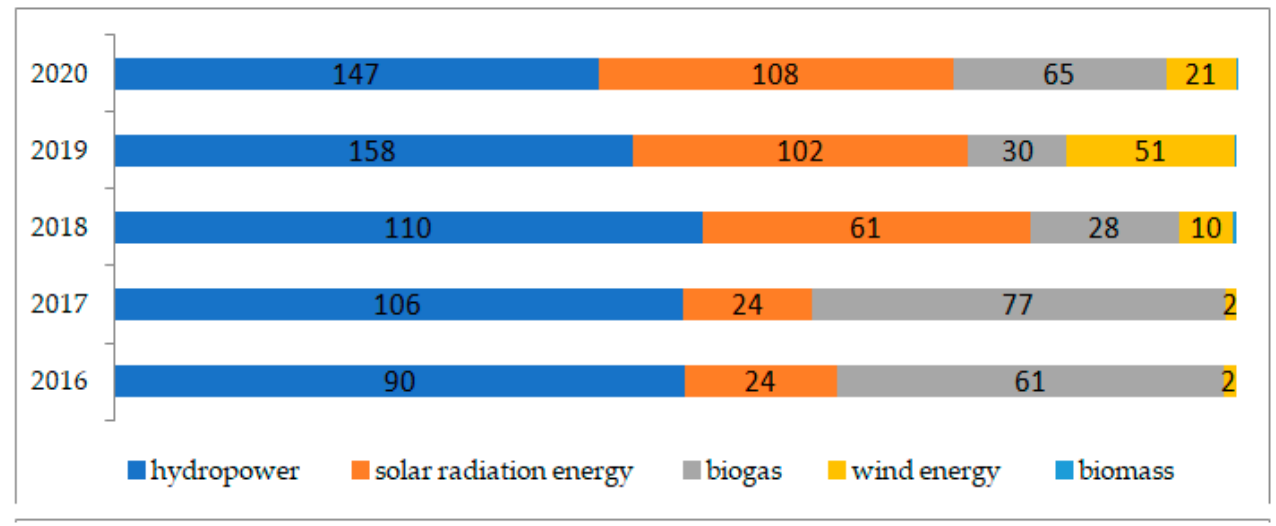

Figure 17. Renewable energy in 2016-2020 (GWh) [62].

The share of the energy sources was, to the greatest extent, in hydropower (Figure 18) (over $40 \%$ ) and in biogas (over 32\%). Later, in the radiation energy (a little at 20\%). To the smallest extent, biomass was $0.5 \%$ and less than $6 \%$ was wind energy [63].

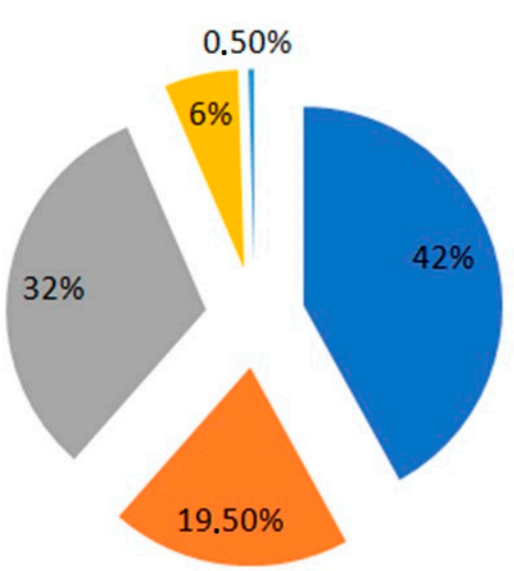

घhdropower $\square$ solar radiation energy $\square$ biogas $\square$ wind energy $\square$ biomass

Figure 18. Share of energy sources in total production in 2020 [64]. 


\subsection{International Conditions Shaping the Development of Renewable Energy}

At the outset, it is important to emphasize the essence of the changing paradigms of international investment regulations, jurisprudence, multi-level and management of public goods. Compliance with human rights, and, in particular, the respect of human rights by investors, indicates a marginal role in investment jurisprudence outside the European Union [65].

Renewable energy is a response to the most pressing socio-economic challenges and climate change. It is important to increase investments in renewable energy [66].

Figure 19 below shows threshold assumptions shaping the development of renewable energy in the international environment.

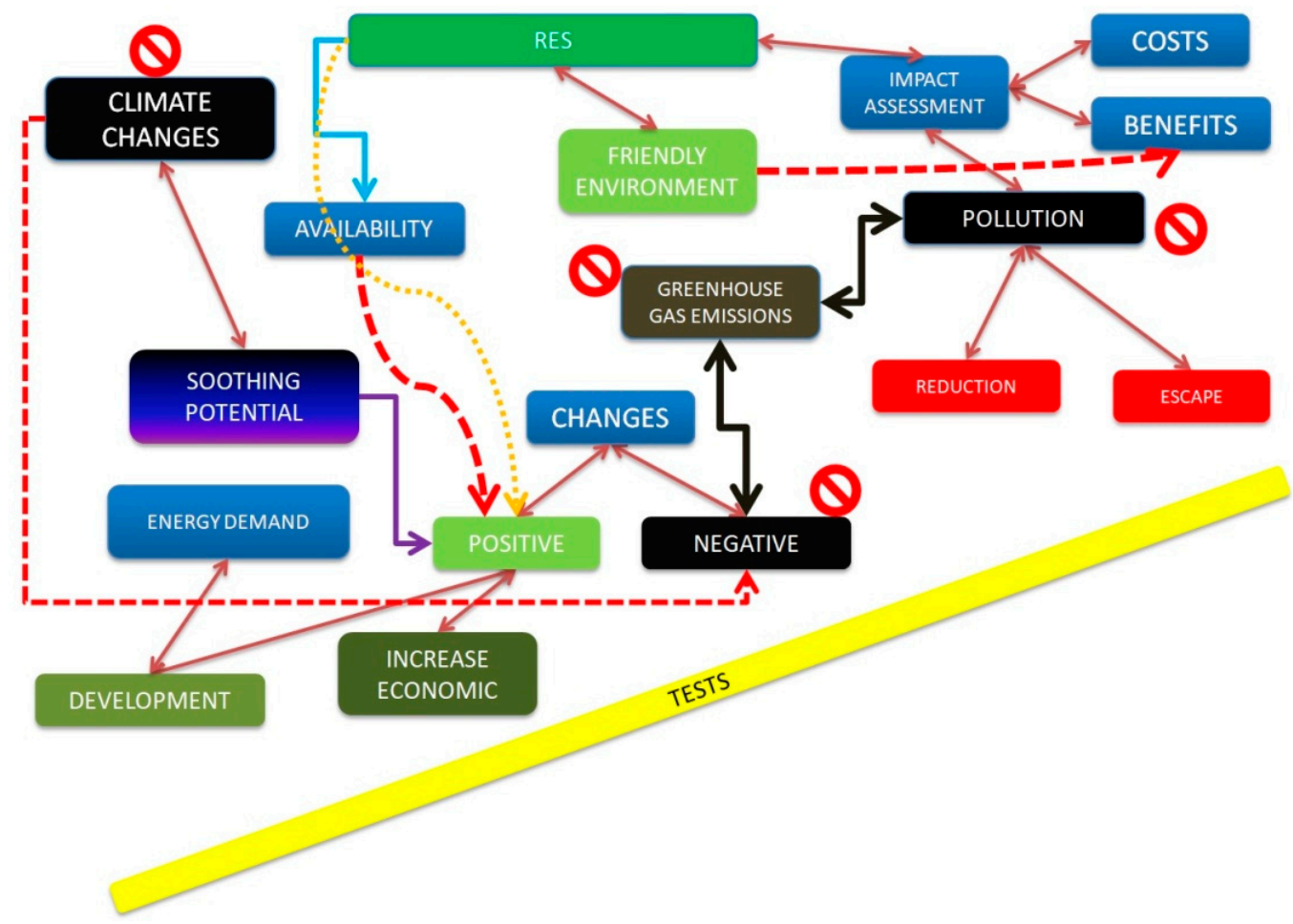

Figure 19. Threshold assumptions shaping the development of renewable energy in the international environment. Source: own study.

The lack of domestic investment can trigger an influx of foreign investment that may be subject to the requirements of those regulated by a number of economic treaties. The role of the most privileged national treatment in the context of bilateral agreements is envisaged through a comprehensive analysis of the efficiency requirements in international agreements in the direction of assessing their impact on the further development of renewable energy.

Renewable energy requires innovation, technology and research, and this comes at a cost. Countries with no resources for renewable energy consciously seek support from foreign investors in return for benefits. In the international economy, there is an emphasis on innovation, technology and expertise. High-tech goods are used by countries to attract foreign investment in renewable energy. This is the cause of international disputes.

The renewable energy sector is regulated by environmental standards (international and national). The key factor is the impact of standards that belong to a different sector and that significantly influence the development of renewable energy. International economic regulations influence the development of renewable energies, which are an essential part of climate change mitigation. Investments in renewable energy demonstrate the ability to broadly and profitably meet all of humanity's energy needs without the risk of shortages and environmental problems. Beneficiary countries typically argue that PR can bring 
significant benefits to a country's development by requiring investors to export, train and transfer technology.

The following Figure 20 presents the assumptions of the typology of differences and prohibitions according to the policy.

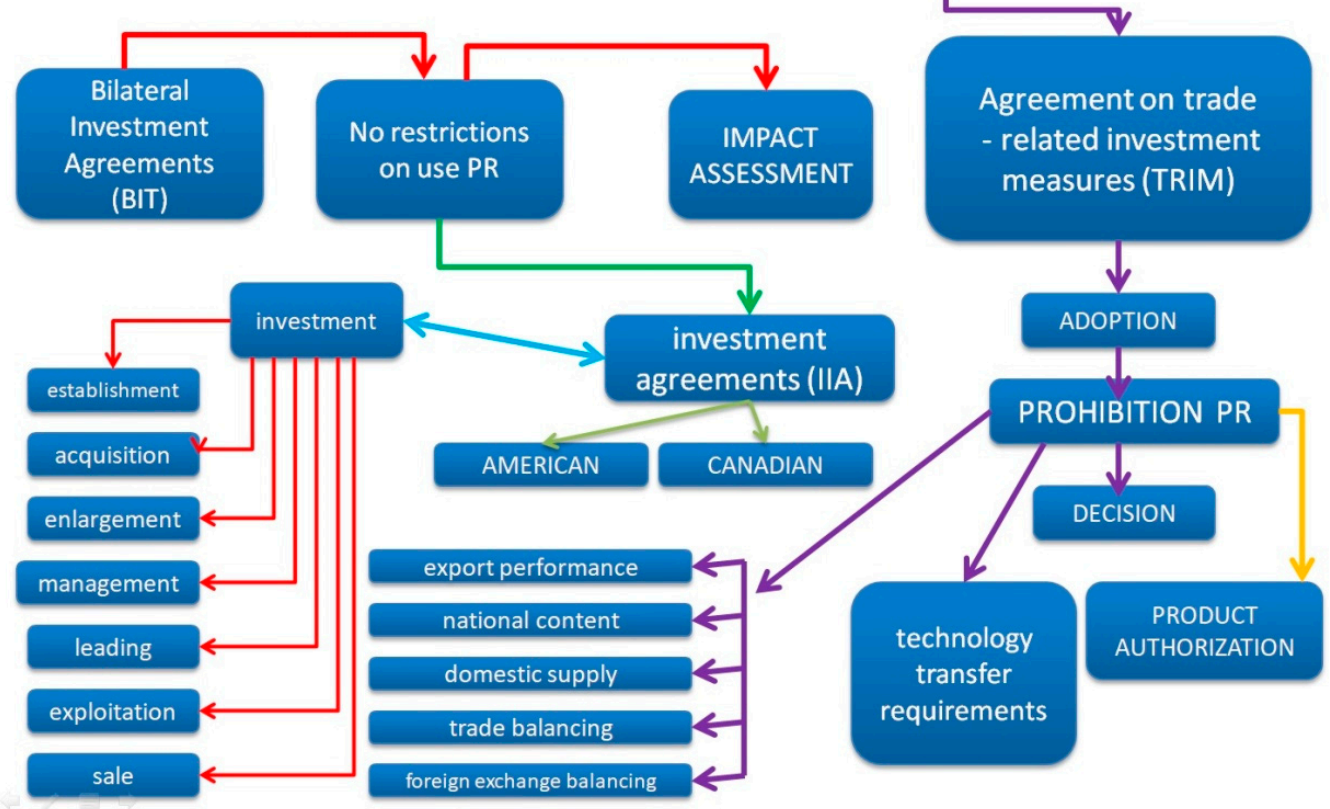

Figure 20. Assumptions of the typology of differences and prohibitions according to the policy. Source: own study.

It should be emphasized that there are no restrictions on the use of PRs in bilateral investment treaties, but US and Canadian international investment treaties explicitly prohibit PR being generated when investments are accepted and immediately after their adoption. Two of these situations contain a list of prohibited PRs that go beyond specific events. Prohibited FPs include technology transfer and product authorization requirements and export performance, domestic content, domestic supply, trade balancing and foreign exchange balancing, in connection with the establishment, acquisition, extension, management, operation, operation or sale of investments.

While there are benefits from investments, there may also be disadvantages with them, leading to different problems for the host country, as shown in Figure 21.

It turns out that FDI (Figure 21) can cause negative side effects, such as environmental degradation, violation of labor and human rights, limited technology transfer under the pretext of a lack of absorption capacity, displacement of labor from domestic industry leading to job losses, anti-competitive activities such as abuse of a dominant position by foreign investors and transfer pricing that unfairly reduces taxes paid to the host country. International investment law defines the rules ensuring access of foreign investments to the markets of the host country and protection of investments against risk (political risk). It places a specific set of investment protection obligations on host countries, including protection against expropriation without compensation, and allows access to financial compensation through an investor-state decision when the host country breaches its protection obligation.

The main source of international investment law comes from other treaties, sometimes called interinstitutional agreements, which include Preferential Trade and Investment Agreements (PTIAs); they relate to investment and bilateral investment treaties (comprehensive investment rules, interinstitutional agreements, double taxation treaties). 


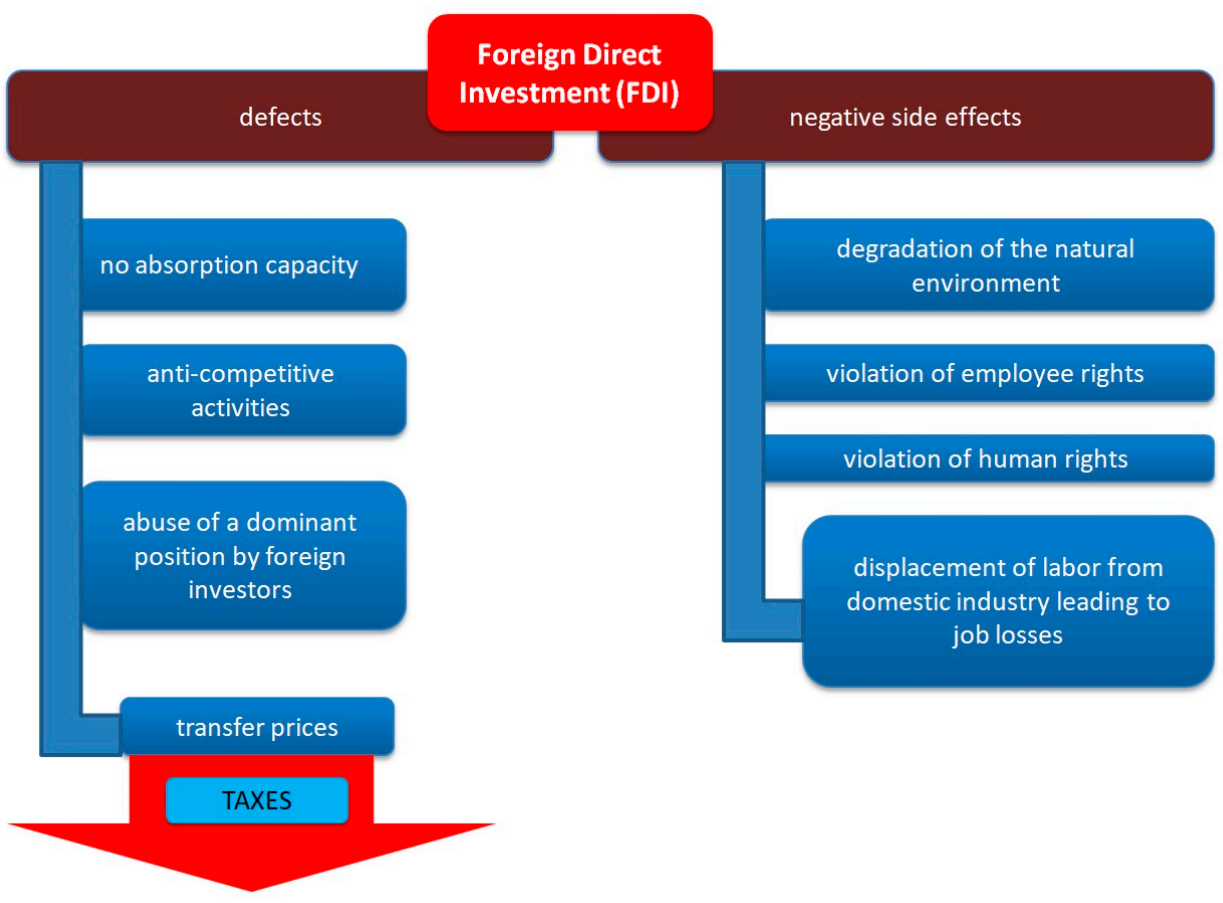

Figure 21. Disadvantages and negative side effects of FDI (Foreign Direct Investment). Source: own study.

Restrictions on renewable energies are likely (no benefit). For the benefit, it would be the negation of free trade. The actions taken indicate a technological gap between developed and developing countries, which could be widened. The development of renewable energy sources becomes crucial [66].

There are two key findings for contemporary consumer policy. The privatization of water is not against the interests of consumers. The privatization of water services is not against the right of consumers or people to water, subject to billing approval. There has been a strengthening of consumer protection in the growing sector of water services. The arbitral tribunal found the human right to water a valid counter-claim. There have been efforts to address non-economic issues such as human rights in investment treaties.

The role of non-governmental organizations dealing with environmental protection in disputes concerning the public interest in the investor-state aspect indicates consumer protection. It turns out that in the case of consumer disputes in the public interest, the submission of a counterclaim is not allowed. It is crucial to protect investors by examining the non-economic aspects of water services, including consumer rights. Investor-state disputes in the water sector pave the way for the protection of the right to other public services, such as energy. This is an undeniable contribution to action in this area [67].

\section{Results}

Poland, as a result of the political and economic changes that took place in the 20th century, only relatively recently started activities aimed at supporting renewable energy in the sector and investing in it. It should be emphasized, however, that a significant reduction in emissions of air pollution occurred in Poland in the 1990s as a result of the economic transformation. At that time, obsolete technologies causing significant environmental pollution were: eliminated and introduced changes in the energy sector aimed at improving the efficiency of fuel use or replacing them with fuels that resulted in lower emissions of pollutants. The most popular is the co-firing of biomass with coal in the existing power boilers from the domestic energy and heating sectors [68].

The growing demand for electricity and the fact that the transmission infrastructure in rural areas requires modernization makes it necessary for Poland to undertake projects requiring huge investment outlays. It also requires changes in management and transfer of 
knowledge on counteracting low-mountain emissions in the headquarters and local selfgovernment. Community-based energy cooperatives that produce energy from renewable energy sources and use it for their own needs can play a special role. This may bring measurable health, social and environmental benefits, leading to an improvement in the quality of life of the inhabitants of Poland.

Figure 22 shows the model projections of fuel prices in imports to the EU as the basis for identifying trends in fuel price development.

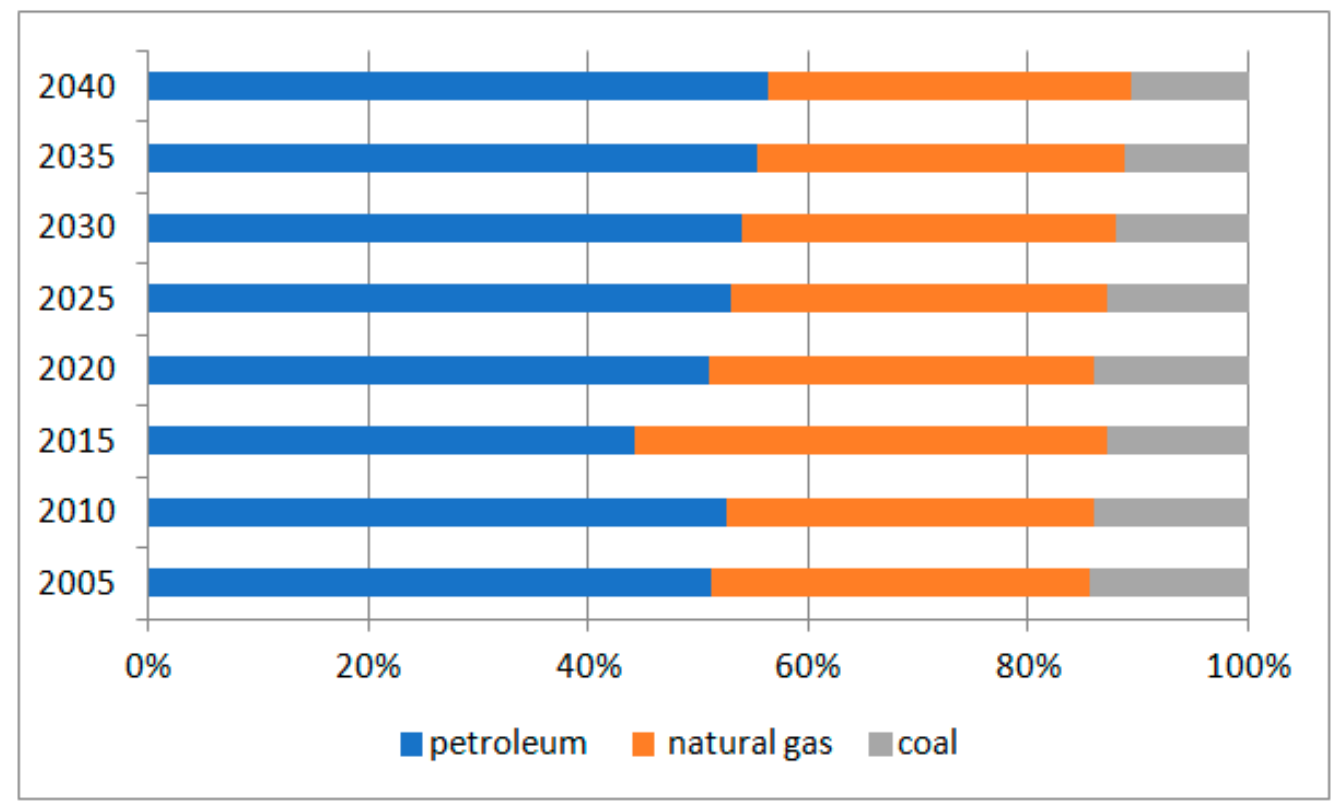

Figure 22. Forecast of fuel prices in imports to the EU [69].

A forecast of fuel prices in imports to the European Union in percentage terms was made - the entire estimate indicates an increase in all individual prices of the raw materials concerned. Polish researchers estimate that crude oil will increase the most (to approximately 15\%), followed by natural gas (to approximately $9 \%$ ) and hard coal (to approximately $3 \%$ ). The increase shows that crude oil has more than doubled. The price of hard coal will increase more as the more RES develops. The simulations show proportionality in the growth of crude oil, the natural phase and the hard coal. The chart below presents the average wholesale electricity prices on the EU market. below.

Average wholesale electricity prices on the spot market are presented in Figure 23

In the "Polish Energy Policy until 2040" projections of prices for end users (consuming energy for their own use) were published, which were based on the projection of average system costs, taking into account the estimates of costs related to the operation of individual support systems in Poland, the level of taxation and rates of transmission and distribution fees. The projections of electricity prices include the costs related to the operation of support systems for energy produced in renewable energy sources, cogeneration and for projects aimed at improving the efficiency of energy use. The analysis also assumed a capacity payment mechanism. The forecast prices are the average prices offered under full and split agreements including taxes. According to the results obtained, electricity prices are expected to gradually increase in all three considered groups of final recipients. The main factor determining the forecasted growth are the growing costs of purchasing $\mathrm{CO}_{2}$ emission allowances and the costs of developing zero-emission technologies. 


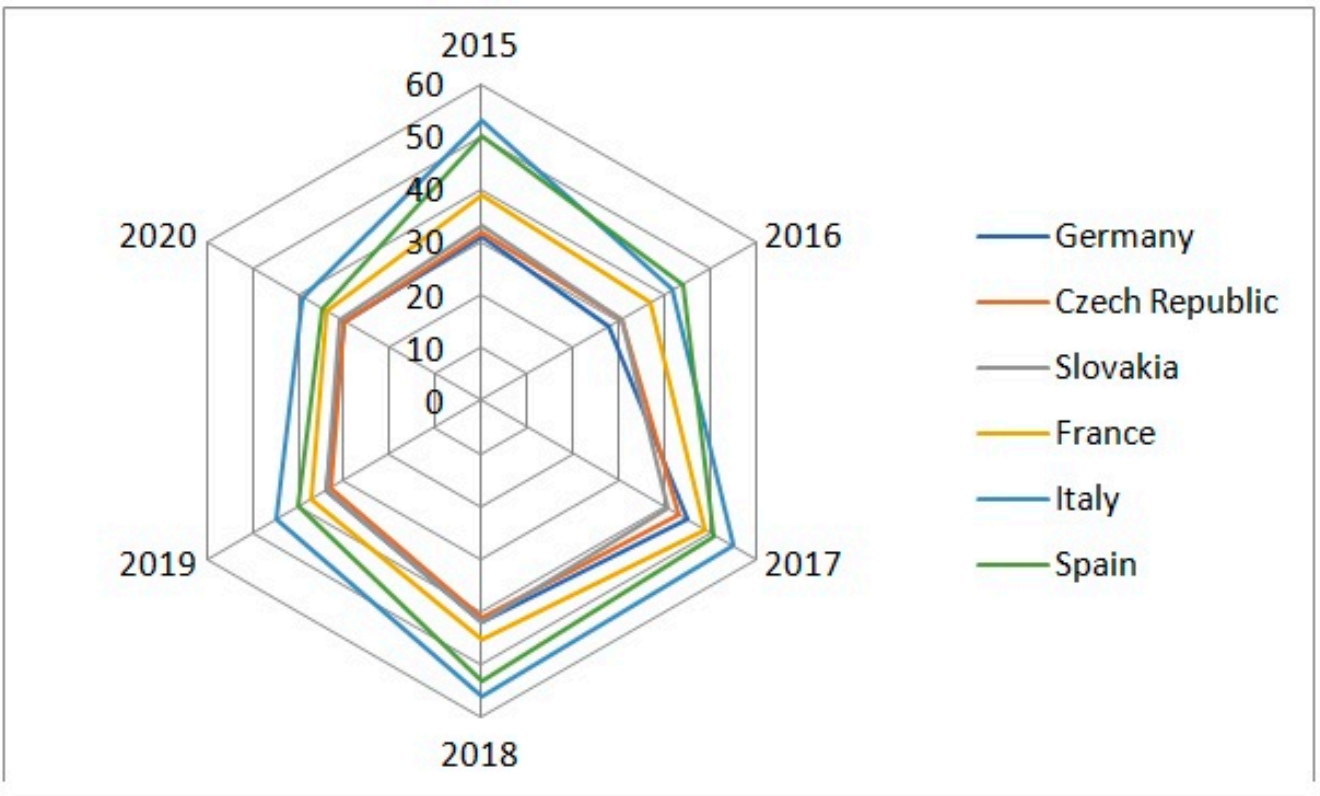

Figure 23. Average wholesale electricity prices on the spot market (EUR/MWh) [70].

The report prepared by the Institute for Renewable Energy (EC BREC IEO) allows to indicate the forecast of production costs and prices of electricity (wholesale) until 2040 in Poland (Figure 24), showing an upward trend in both energy prices and costs. It is worth adding that we also notice cost stabilization-proportional energy appreciation.

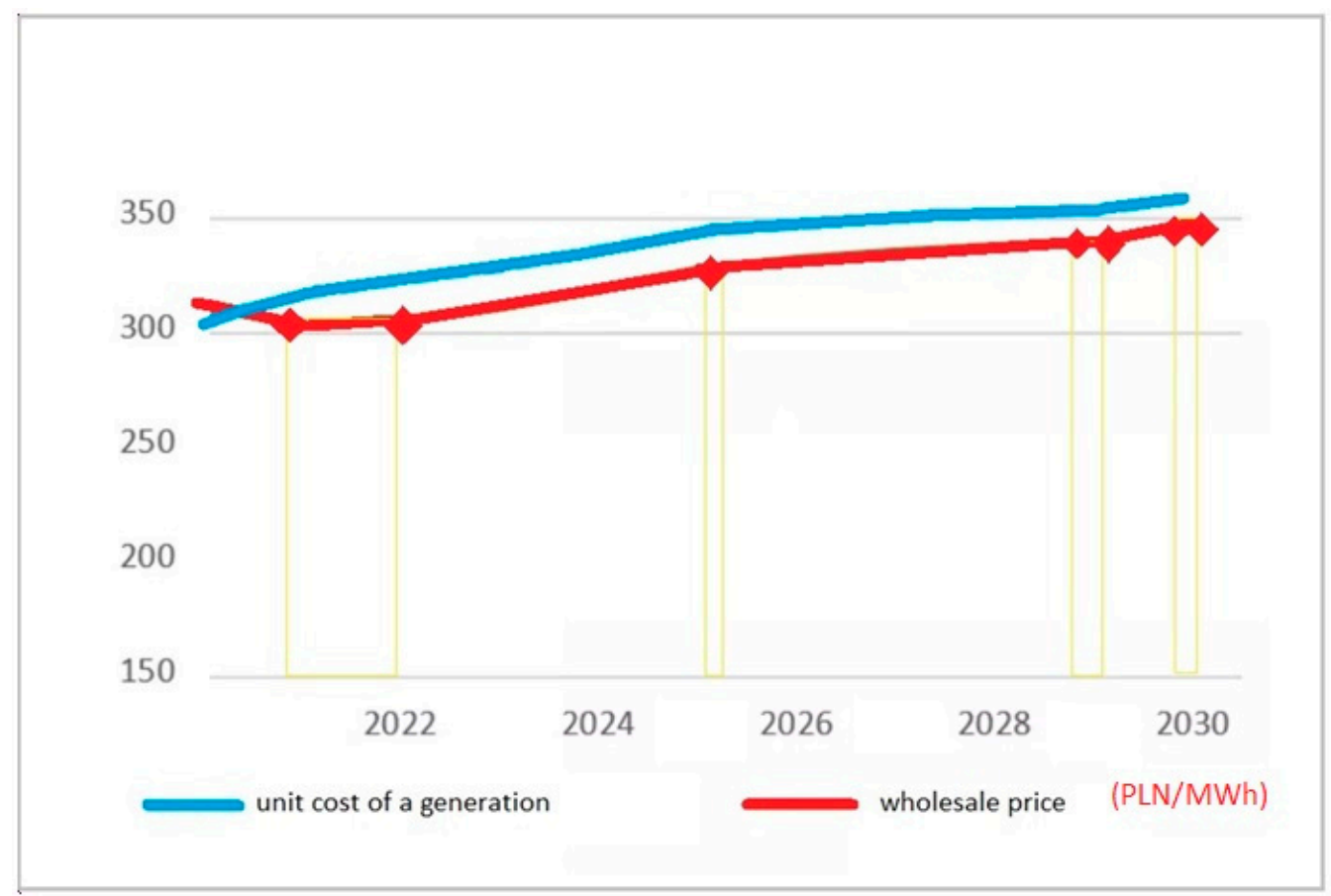

Figure 24. Forecast of electricity generation costs and prices until 2040 in Poland (PLN/MWh) [71].

The increase in the prices of $\mathrm{CO}_{2}$ emission allowances is one of the main reasons for the increase in energy prices in Poland. The energy sector is based on coal-fired generating units, burdened to the greatest extent by emission costs. The prices of $\mathrm{CO}_{2}$ emission allowances are transferred into energy prices and tariffs of heating companies and affect the increase in charges for consumers for the supply of electricity and heat. This makes it necessary to take measures to reduce the emission intensity of generation assets. Failure to 
do so, with rising costs of $\mathrm{CO}_{2}$ emissions, would further increase the cost of energy and heat, and thus increase the energy poverty of citizens. As a result of the delay in the energy transformation, an unjustified belief about its growing costs could arise, resulting in the belief that it is necessary to abandon this process. This would lead to even higher energy prices and no transition benefits.

The high emission factor of the Polish coal power industry and the high prices of $\mathrm{CO}_{2}$ emission allowances will result in a situation in which the main component of electricity generation costs will be costs related to emission charges. Thanks to the transformation, it will be possible to reduce the total $\mathrm{CO}_{2}$ emissions from electricity production by almost $25 \%$ in 2025. Prices will stabilize at levels where closed units would have been profitable had they not been shut down sooner. The structure of the energy mix between Poland and Germany in the production of electricity is presented below (Figure 25).

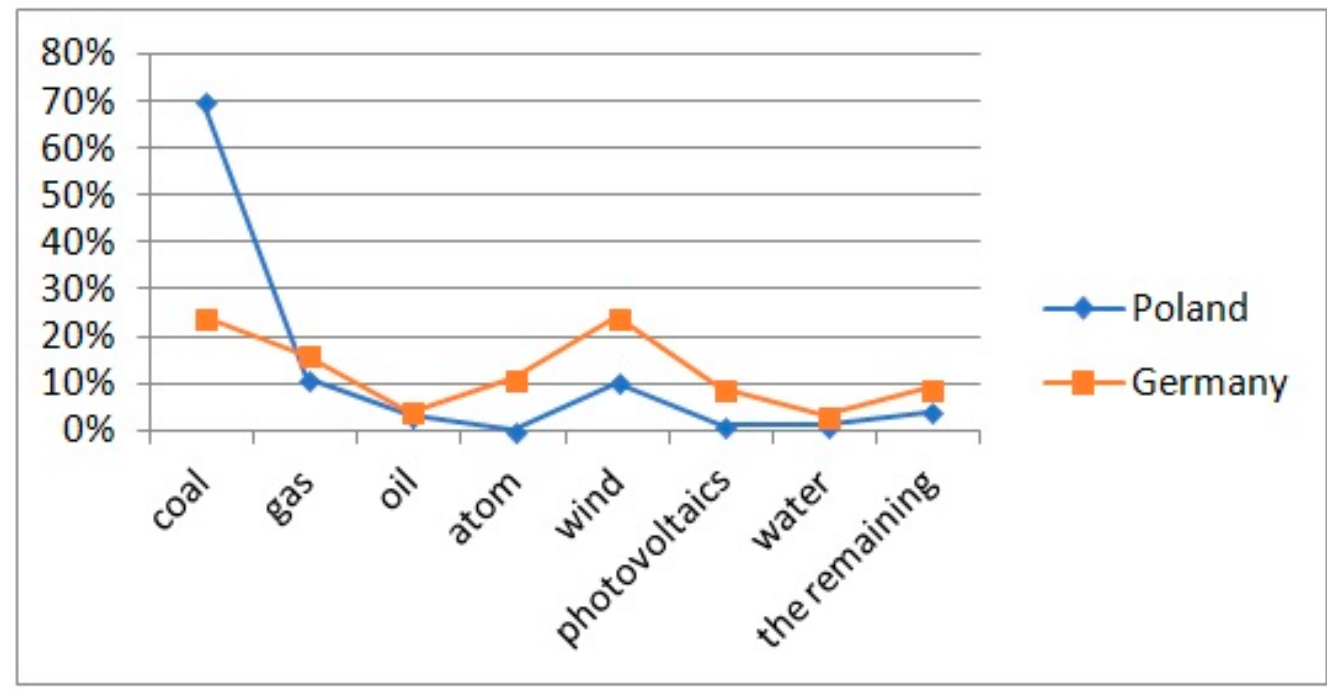

Figure 25. Structure of the energy mix of Poland and Germany regarding electricity production $(\%)$ [72].

The current energy policy of Germany has been implemented through strategic elements of the implementation of the national climate goals in the German energy sector: replacing coal-fired cogeneration with gas cogeneration, reducing electricity production from coal-fired units, increasing the use of renewable energy sources.

It seems natural that Germany is more successful in action than Poland (Figure 26). The percentage arguments presented below are intended to indicate the possibility of Germany acting — as a benchmark and position of Poland-as a learning state.

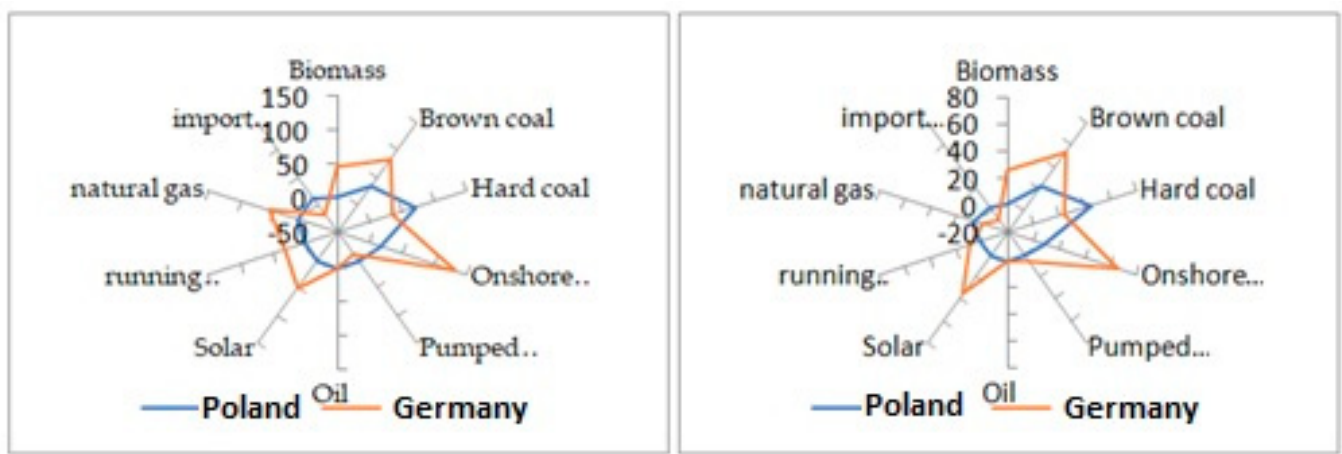

Figure 26. Comparison of Poland and Germany 2020 [73].

Net electricity production towards electricity supply in 2020 was as follows (Figure 27): to the greatest extent-wind (less than 60\%), then brown coal (less than $46 \%$ ). Then, 
successively, nuclear energy (less than 30\%) and gas 30.7\%, and solar and biomass (less than $23 \%$ and $30 \%$ ). Hydropower (slightly over 11\%) and oil less than $2 \%$ were noticed. The following Figure 28 shows net energy production for the public grid in 2021 (first half).

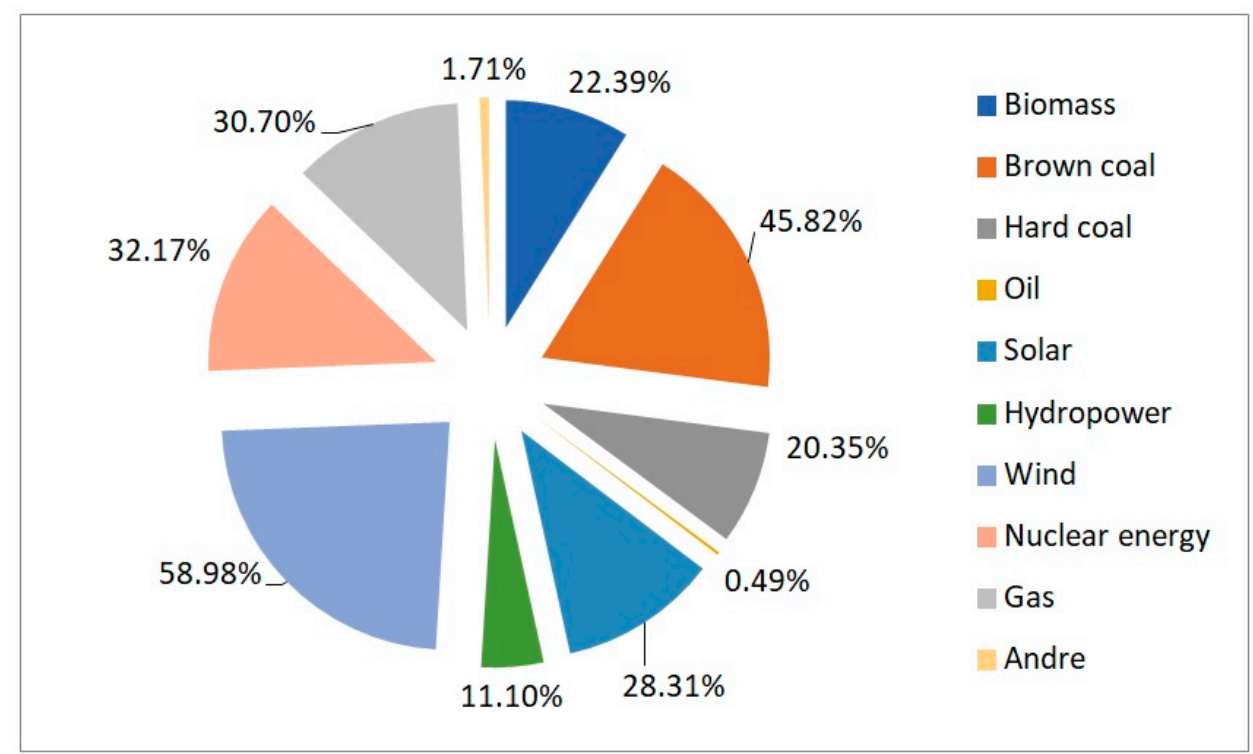

Figure 27. Net electricity production for electricity supply 2020 [74].

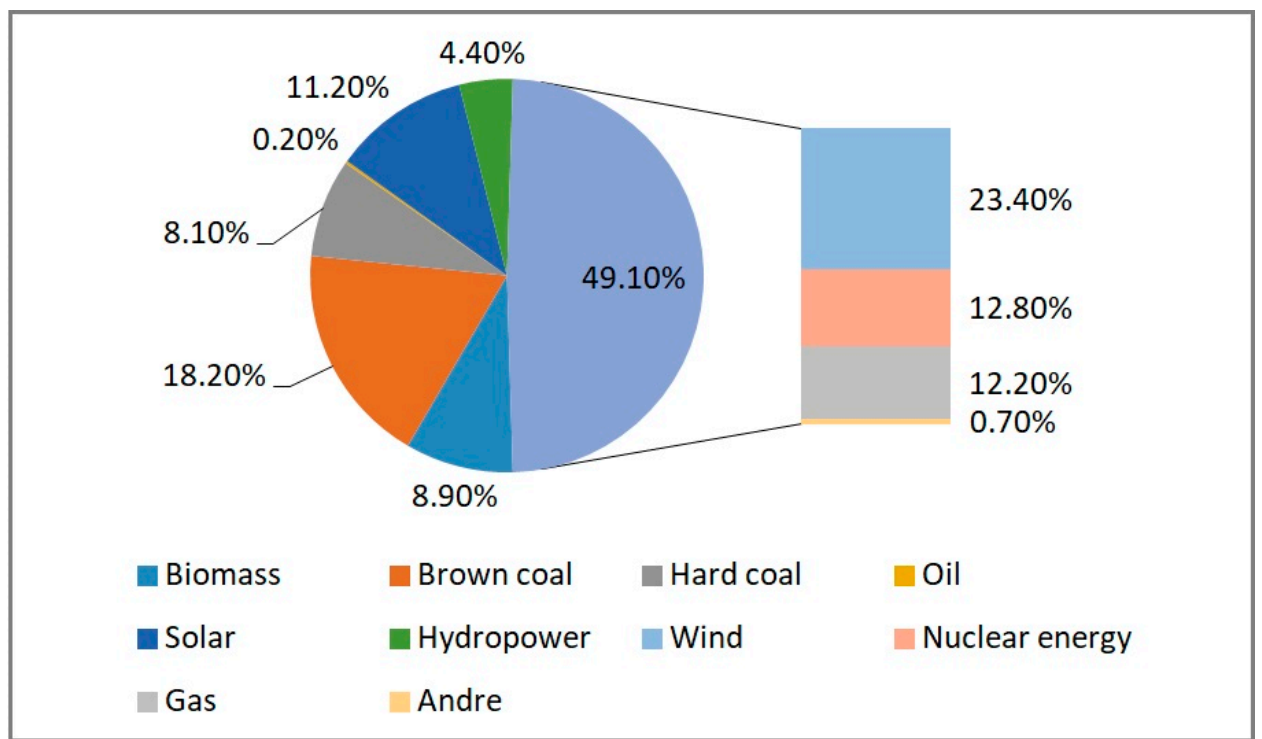

Figure 28. Generation of energy for the public grid (from January 2021 to August 2021) [75].

The largest amount of net energy generated for the public grid in the first half of 2021 was recorded in winds-(less than 50\%), then brown coal (slightly less than 20\%) and solar and biomass, where the former was slightly more than, and the latter less than $10 \%$. A similar situation occurs with gas (12.2\%) and nuclear energy $(12.8 \%)$. The remaining share is andre and oil, respectively less than $1 \%$ and $0.2 \%$. The following Figure 17 shows the factors of market value in Germany (2020).

The factors of production value in Germany (Figure 29) have the most in running water-100.20\% and pumped storage-over $100 \%$. Later, almost $100 \%$ brown coal-98.30\%, gas-96.60\%. In total, it was $96.90 \%$, the least was $80 \%$ solar and oil, and $3 \%$ more onshore wind. 


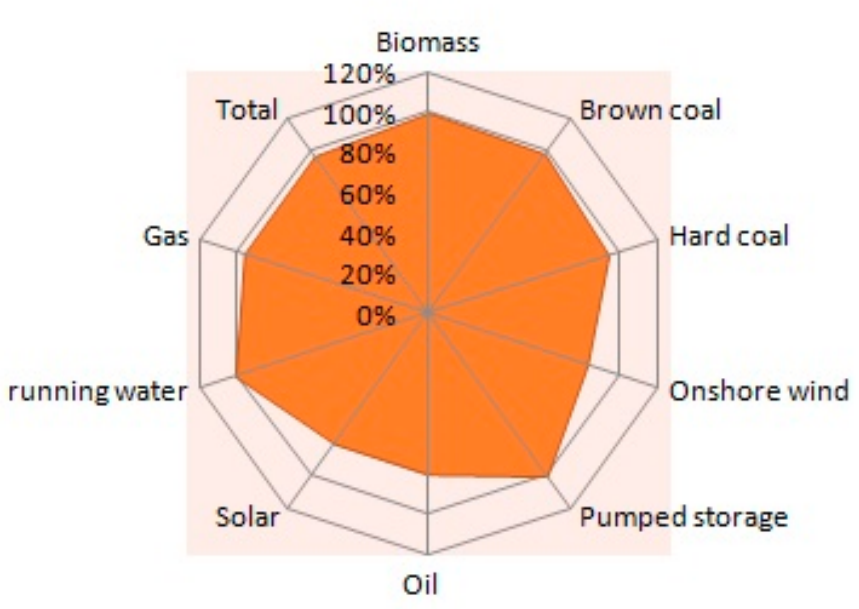

Figure 29. Market value factors in Germany (2020) [76].

Figure 30 below shows the net electricity production from a power plant.

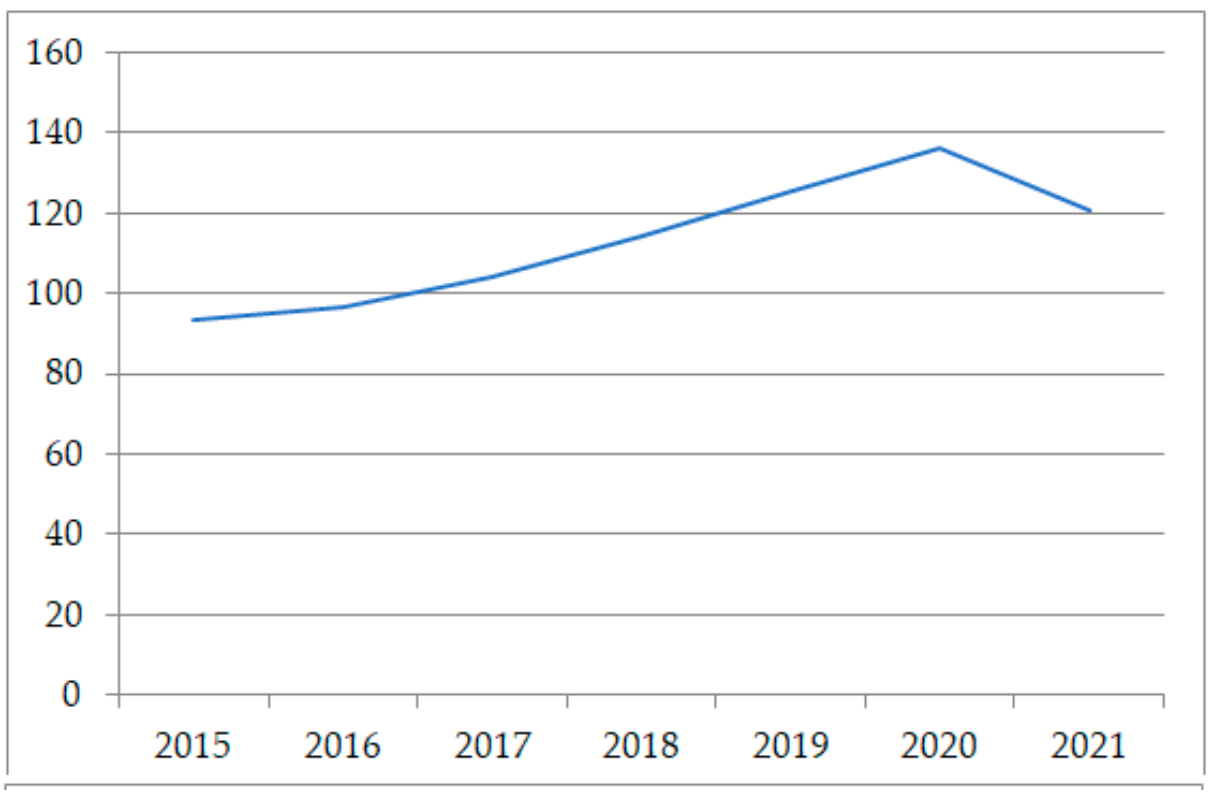

Figure 30. Net electricity production for electricity supply from 2015 to 2021 (Kwh) [77].

Initially, from the study period-2015, an upward trend was noticed, starting from about $95 \mathrm{Kwh}$ until mid-2016 with a result of about $97 \mathrm{Kwh}$; then 2 years from 2017 to 2020, an average increase of just over $10 \mathrm{Kwh}$. A definite decrease is visible from 2020 (Q1 and Q2) with a trend of over $15 \mathrm{Kwh}$. It is estimated that the tendency will be realized towards a greater decline by as much as $20-45 \mathrm{Kwh}$, and even 50-60 Kwh.

Figure 31 shows an estimate of the average planned electricity production in Germany. 

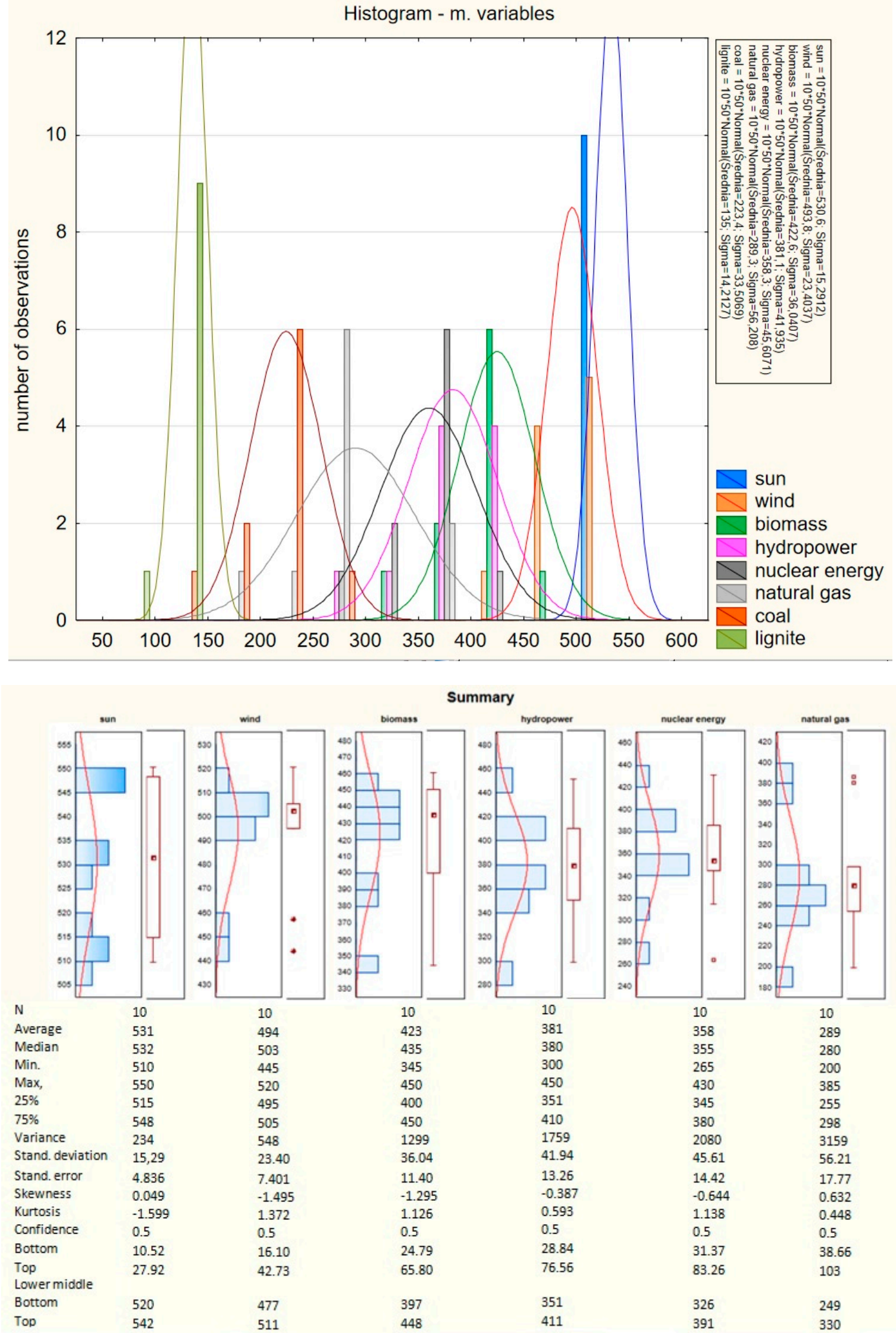

Figure 31. Estimation of the average planned electricity production in Germany (based on the actual annual average using the program STATISTICA). 
In the first case, for (sun) kurtosis is negative, exactly $\mathrm{k}=-1.599,(\mathrm{k}<0)$ platokurtic kurtosis, in this case, we say that kurtosis is negative, i.e., the values of the feature have a lower concentration than in the normal distribution), which may be that the distribution of values in the population is probably inaccurate and one cannot be sure of the tests used, as they may give erroneous results. However, for the remaining ones, it is positive $(\mathrm{k}>0)$ but not equal to 0 -leptokurtic kurtosis. The values of the feature have a greater concentration than in the case of normal distribution, which means that the other presented results are correct-for (wind), (biomass), (hydropower), (nuclear energy), (natural gas). When analyzing the standard deviation, it is worth indicating in the graph (Figure 32).

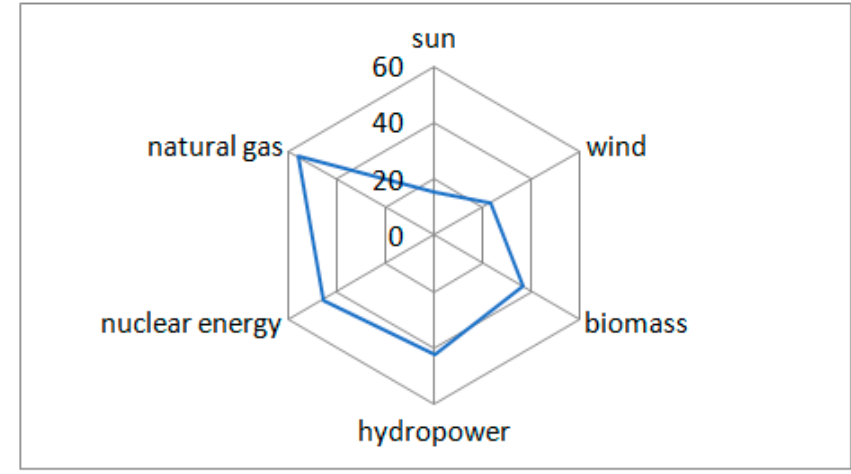

Figure 32. Standard deviation of RES [78].

Figure 32 shows that natural gas has the greatest impact on changes-over 50 research units of the annual average, then similarly we have (nuclear energy), (hydropower), over 40, biomass over 30, lifts over 20 and sun just over 15 .

The next calculations needed for the interpretation are presented in Figures 33 and 34.

lignite

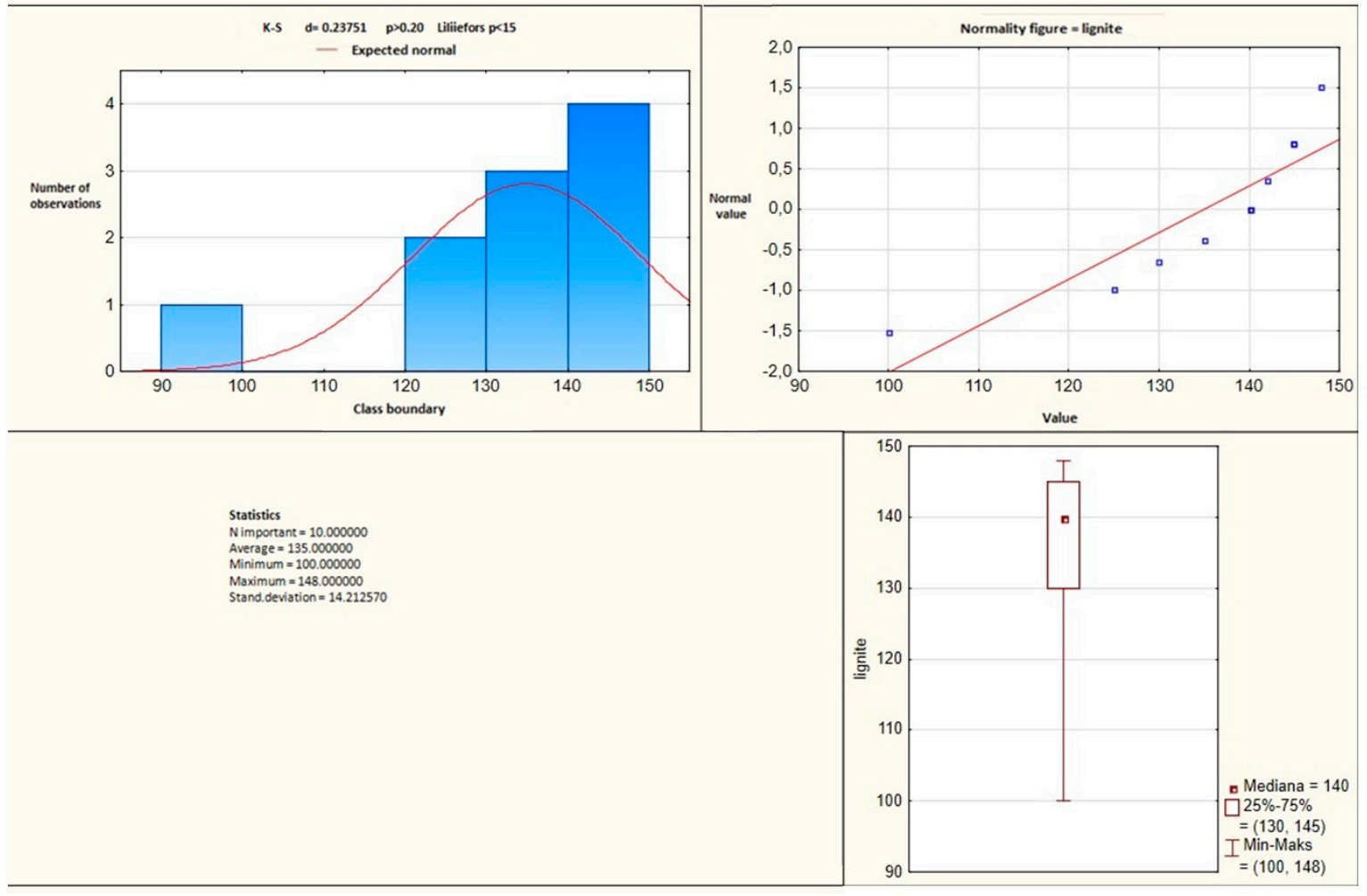

Figure 33. Statistical calculations for lignite. 


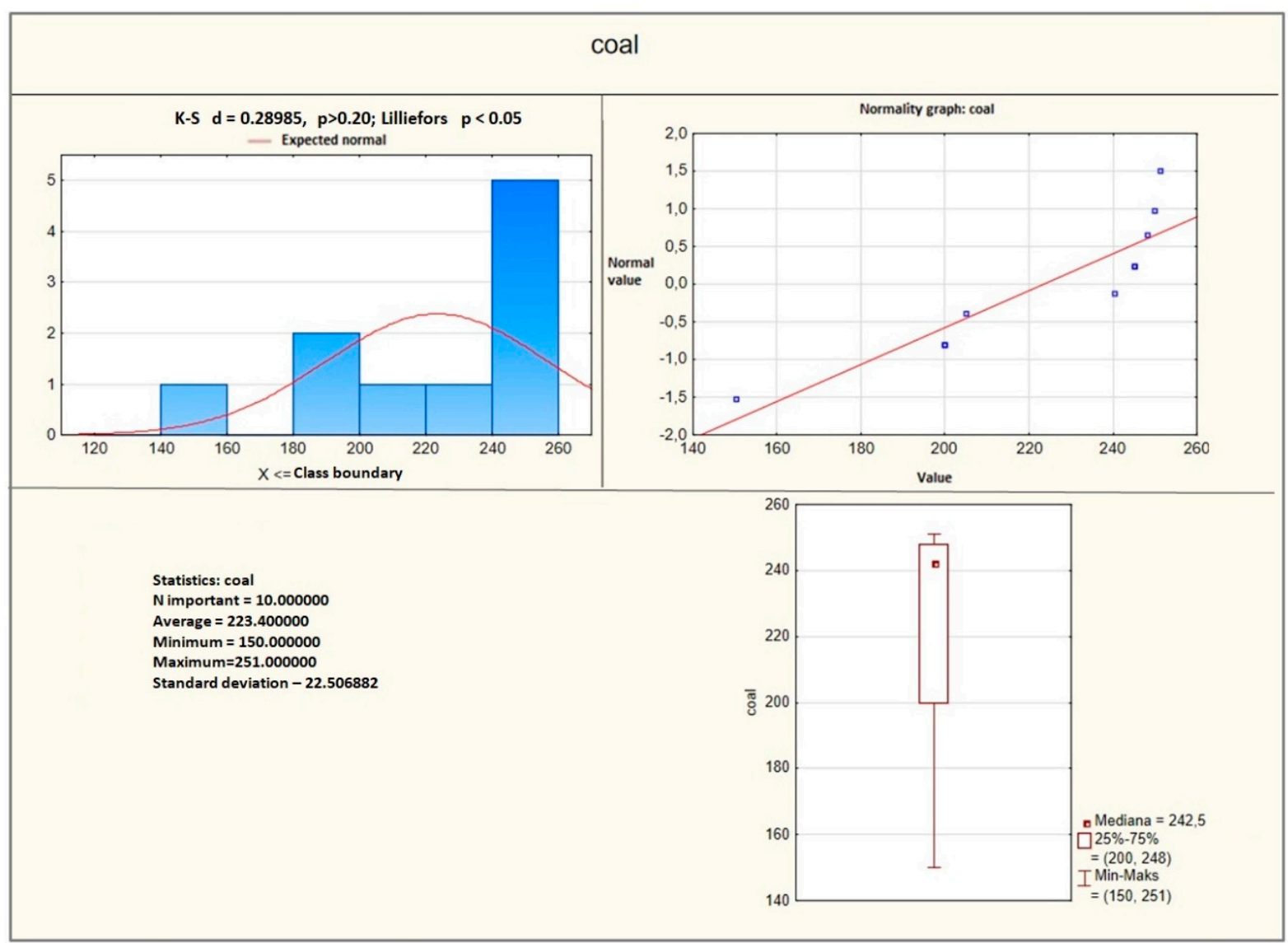

Figure 34. Statistical calculations for coal.

By observing the scatter plots, it is possible to deduce what kind of relationship "we are dealing with". The interpretation of the chart allows for the conclusion of a positive relationship (with a strong force $r=(0,1)$ ). It should be emphasized that an increase in the value of one feature causes an increase in the average values of the second feature. The numerical solution of the indicated correlation is the correlation coefficient that identifies itself with the range in the numerical interval $(-1 ; 1)$. The correlations of the studied variables for $r$ are presented below: $-1,-0.8,-0.6,-0.4,-0.2,0,0.2,0.4,0.6,0.8$ and 1 .

The values adopted for the correlation relationships are presented in Table 1 and description for correlation relationships in presented Table 2.

Table 1. Correlation in terms of the possibilities of the energy market in Germany based on archival data 2011-2021.

\begin{tabular}{ccccccccc}
\hline Type of Energy & $\mathbf{- 0 . 8 0}$ & $\mathbf{- 0 . 6 0}$ & $\mathbf{- 0 . 4 0}$ & $\mathbf{- 0 . 2 0}$ & $\mathbf{0 . 2 0}$ & $\mathbf{0 . 4 0}$ & $\mathbf{0 . 6 0}$ & $\mathbf{0 . 8 0}$ \\
\hline Sun & 1.000000 & 0.196284 & -0.124315 & -0.140457 & -0.052545 & 0.303694 & -0.203936 & 0.457063 \\
Wind & 0.196284 & 1.000000 & 0.322893 & 0.323585 & 0.320058 & -0.125717 & 0.257989 & 0.307316 \\
Biomass & -0.124315 & 0.322893 & 1.000000 & 0.946339 & 0.948273 & 0.655891 & 0.911956 & 0.535779 \\
Hydropower & -0.140457 & 0.323595 & 0.946339 & 1.000000 & 0.986108 & 0.533460 & 0.839918 & 0.346192 \\
Nuclear energy & -0.052545 & 0.320058 & 0.948273 & 0.986108 & 1.000000 & 0.564903 & 0.836725 & 0.406254 \\
Natural gas & 0.303694 & -0.125717 & 0.655891 & 0.533460 & 0.564903 & 1.000000 & 0.480395 & 0.556344 \\
Coal & -0.203936 & 0.257989 & 0.911956 & 0.839918 & 0.836725 & 0.480395 & 1.000000 & 0.646290 \\
Lignite & 0.457063 & 0.307316 & 0.535779 & 0.346192 & 0.406254 & 0.556344 & 0.646290 & 1.000000 \\
\hline
\end{tabular}


Table 2. Description for correlation relationships.

\begin{tabular}{cl}
\hline & \multicolumn{1}{c}{ The Strength of Correlation Relationships } \\
\hline below 0.2 & weak correlation (practically no relationship) \\
$0.2-0.4$ & low correlation (clear relationship) \\
$0.4-0.6$ & moderate correlation (significant relationship) \\
$0.6-0.8$ & high correlation (significant dependence) \\
$0.8-0.9$ & very high correlation (very high dependency) \\
$0.9-1.0$ & dependence practically complete \\
\hline
\end{tabular}

Correlation scatter plots can assume a positive linear relationship $(r>0)$, a negative linear relationship $(\mathrm{r}<0)$ and no relationship $(\mathrm{r}-0)$.

The Schuman Foundation and the Adenauer Foundation measured the importance of individual countries in the European Union and their actual impact on the decisions taken in it. Germany is the strongest country in the European Union, but not strong enough to decide about it on its own. Poland was only in 13th place, between Finland and Lithuania [79], as shown in Figure 35.

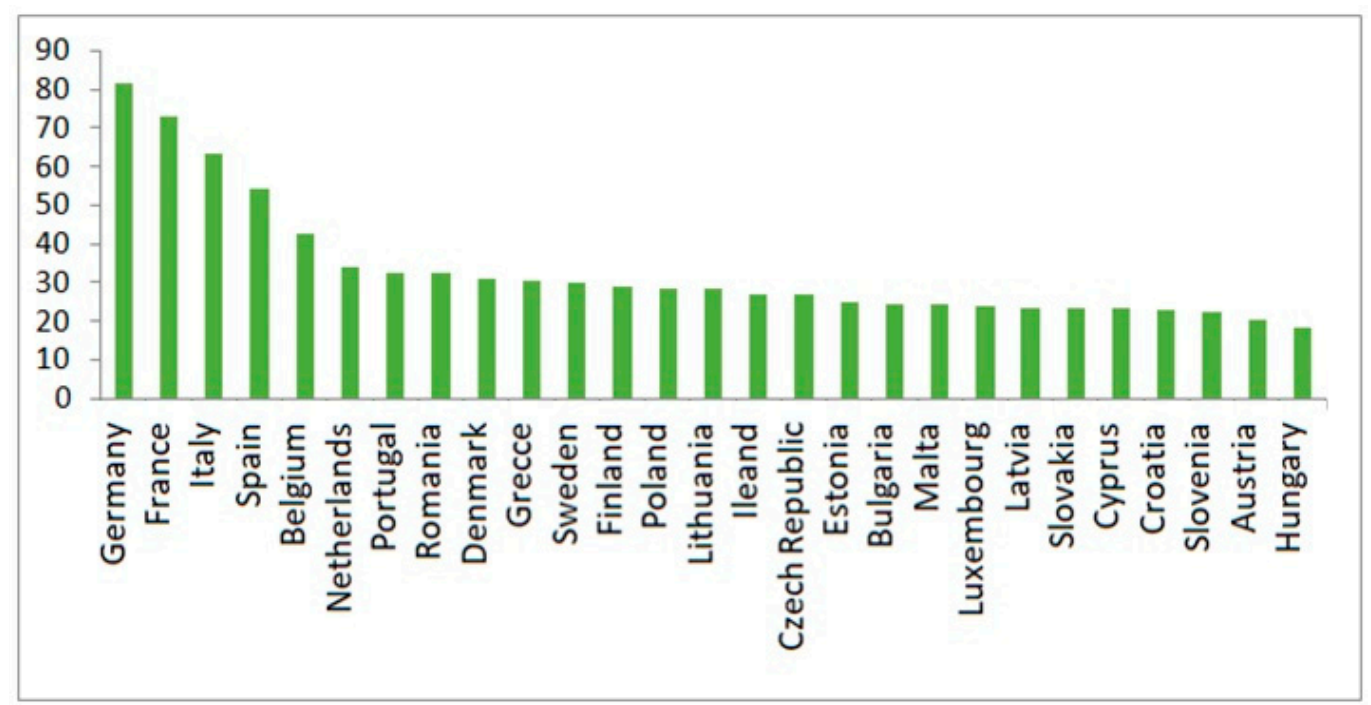

Figure 35. The significance of individual states in terms of the decisions taken [80].

Historically, in the period from 1988 to 2018, it was observed in Poland that a phenomenon consisting in the separation of the relationship between the increase in GDP dynamics and greenhouse gas emissions. An increasing value of GDP does not lead to an increase in the level of emissions, as illustrated in the chart below. In 1988-2018, GHG emissions were reduced by $32 \%$, with almost 3 times GDP growth.

The relation of GDP dynamics to greenhouse gas emissions (1988-2018) is presented in Figure 36.

It should be questioned as to the situation in which Poland will actively strive to be low-carbon. The reason for this assumption is the lack of similarity between the increase in GDP dynamics and the emission of greenhouse gases. 


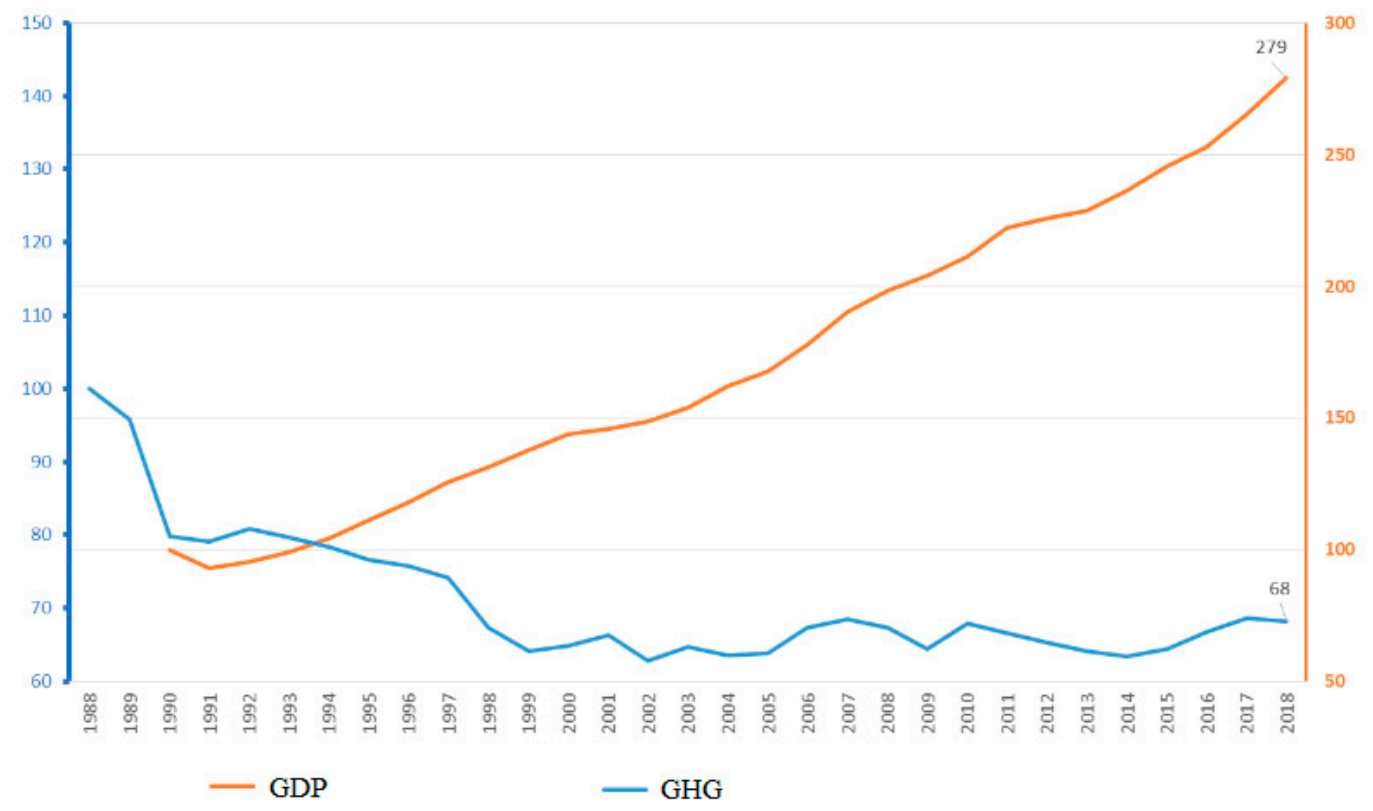

Figure 36. Relation of GDP dynamics to greenhouse gas emissions (1988-2018) [81].

\section{Discussion}

The subject literature often includes topics related to the energy supply sector as a share of global greenhouse gas emissions [82]. The most frequently explored topics are the costs and benefits and the mitigating potential of renewable energy generation, followed by the impact of climate change on electricity production. The research gap is the fact that little attention is paid to Poland and Germany in the research aspect [83]. Thanks to the overview below, it will be possible to take steps towards energy systems in order to acquire the preparation for climate mitigation.

The demand for energy increases [84] with the development of the economy and the increasing opportunities for innovation [85]. As a redundant resource, a stable energy supply is essential for human survival and social development [86].

Renewable energy is highly appreciated for its wide availability and environmental friendliness; therefore, it does not lead to a significant increase in pollution [87].

It turns out that in highly developed countries, the energy demand and final energy consumption can lead to concern. This position was adopted in 2015-2019. This was due to the optimization of the energy source and the optimal use of renewable energy sources.

The subject of climate change and energy systems is most discussed in China, then four times smaller in India and almost two times smaller in Brazil. The energy systems themselves were almost comparable in the US, EU and UK. The subject matter is based on low-carbon emissions in the construction or housing sector. Actions are carried out in such a way as to minimize the effect of climate change. Industrial support in terms of production causes the necessity to use energy resources, which in developed countries is a natural need aimed at satisfying market requirements.

Solar, wind, biomass and nuclear energy, as well as research on hydrogen energy production and energy consumption, are becoming key. It is a real possibility to create patterns, to technically innovate to radically reduce pollution, or even to avoid it [88].

Developing new business models geared towards implementing renewable energy sources is important. Worldwide knowledge and research should be codified and all initiatives should be promoted and determined to eliminate all climate change [82].

The functioning of energy policy in global climate change around the world should be based on the involvement of all possible resources towards creating conditions for the stability of legal regulations aimed at full integration of energy resources in creating reliable security and sustainable development of the energy sector. 
The shape of the entire political dimension is mainly indicated by the state authorities. There are many indications that the PEP40 shows the necessary directions for short-term actions.

Currently, developed countries are easily directing their activities towards the implementation of energy policy [89].

The European Union is taking action both to achieve the assumed emission reduction targets in Europe, but also to cooperate with the rest of the world. Limiting emissions applies to the entire world. It is worth pointing out that any postponement during the climate negotiations may have negative consequences for the environment; even the phenomenon of a temporary reduction in global emissions caused by the crisis, which probably, to some extent, disrupted the benchmarks in 2020 and, in principle, by 2021.

The current directions of the global climate policy related to the reduction of carbon dioxide emissions to the atmosphere make it necessary to further reduce emissions. They may lead to considerations on undertaking transformation efforts in selected sectors of the economy. The presented State Attractiveness Report in terms of Renewable Energy indicates the most attractive countries: the USA, China and India [90,91].

RES companies are valued high. Investors are interested in working with clearly declared countries to achieve zero-emission energy in 2035 [92].

Proposed tax breaks and subsidies in China may not be a guarantee of a boost. The greatest increase in energy is achieved in the Chinese energy mix by hydropower plants. China is a pioneer in this area, which is a side effect.

Individual programs in Poland created the possibility of increasing the power of photovoltaic installations. Commitment to the industrial goals is expected. It seems obvious that the growing costs of obtained energy make it necessary to invest in electricity from renewable sources, the price of which is more favorable. Barriers to the effective implementation of RES in industry are regulatory uncertainty and an inconsistent approach to climate and energy policy.

The trends and goals are clearly set as a full recovery after the pandemic period, especially for enterprises. Those that will participate in RES are to be considered more competitive. RES is used by countries that have radical allies in their state authorities for the correct interpretation of energy policy regulations and regulations.

The increase in energy demand (surplus) is mostly covered by the increase in the capacity of installations producing green energy. Despite the fact that due to the pandemic, investments in renewable energy have slowed down in China, France, Germany, Portugal, Brazil, India, Vietnam and Chile, wind and solar projects are systematically manned by 2025 and will soon reach even half of the proposed plan-such a position was presented by the International Energy Agency. Moreover, there is noticeable interest from investors towards windmills and photovoltaic panels.

\section{Conclusions}

Energy demand is increasing, as is economic growth. The authors state that this is an inevitable situation. Renewable energy is mainly met by highly developed countries.

On the one hand, the pandemic slowed down economic growth, and on the other hand, it focused on the expansion of technological channels.

Everyone would like to make a situation in which it would be possible to develop renewable energy sources to the maximum, save and contribute to the reduction of pollution and ultimately stop the negative effects of climate change negatively affecting our world. There is no radical procedure, and preliminary declarations will not achieve the goals that have been set. Highly developed countries are more prone to RES development. Entrepreneurs are concerned to what extent the government-led energy policy will guarantee the implementation of these demands.

It is worth emphasizing that the introduction of changes will also be related to new jobs. Certainly, Germany's position and achievements in the field of energy transformation [93] are a good example for Poland, which does not necessarily have to be compared with 
the unrealistic vision of catching up with the most developed country. It is worth setting realistic goals, which guarantees the possibility of further proceeding in this area and may probably create a base for action towards the implementation of postulates or assistance. Without reliable information, no one will be able to really help.

The pandemic situation now appears to be under control, although still uncertain. This means that the value of a threat can increase instantly without any particular reason or logic. After the recent fight against the pandemic, the world should be prepared to act accordingly.

The presented assumptions of the energy policy until 2040 seem realistic [93]. The authors wonder whether the deadline for implementation is too short and whether more radical changes should be introduced in order to create real opportunities for each link cooperating on the international scene in this regard. It leaves no doubt that close cooperation of all European Union countries is required. Poland must adapt to the requirements of the European Union community.

It is disturbing that Poland, despite economic growth, does not achieve an even growth in RES. Each of us is required to be involved, open to innovations and to act in accordance with the energy policy of the European Union.

Basic management functions (planning, organizing, motivating and controlling) are also necessary. Failure to meet the requirements of the energy policy should be carefully verified and consequently drawn up in order to involve the whole world.

It seems that the lack of sanctions may reduce the effectiveness of the implementation of the objective of this undertaking.

The key is radical and decisive decision-making on the set goal of a radical recovery of the economy. The authors doubt whether by 2050 the European Union will be the first in terms of climate neutrality.

It seems natural to say that the prices for the distribution of polluting carbon emissions will increase with increasing emissions of renewable energy sources. Another observation is that the carbon pollutant emission equipment is no longer new and contributes to further depreciation. Depreciation or inefficiency of a system not classified as RES may ultimately result in the use of clean energy, but in a long-term mode.

Author Contributions: Conceptualization, T.J. and H.W.; methodology, T.J. and H.W.; software, T.J. and H.W.; validation, T.J. and H.W., formal analysis, T.J. and H.W.; investigation, T.J. and H.W.; resources, T.J. and H.W.; data curation, T.J. and H.W.; writing-original draft preparation, T.J. and H.W.; writing-review and editing, T.J. and H.W.; visualization, T.J. and H.W.; supervision, T.J. and H.W.; project administration, T.J. and H.W.; funding acquisition, T.J. and H.W. All authors have read and agreed to the published version of the manuscript.

Funding: The article was funded from research funds from the Academy of War Art in Warsaw.

Conflicts of Interest: The authors declare no conflict of interest.

\section{References}

1. Lund, H. Renewable energy strategies for sustainable development. Energy 2007, 32, 912-919. [CrossRef]

2. Bukowski, M.; Majewski, J.; Sobolewska, A. Macroeconomic Electric Energy Production Efficiency of Photovoltaic Panels in Single-Family Homes in Poland. Energies 2021, 14, 126. [CrossRef]

3. Kakaras, E.; Koumanakos, A.K.; Doukelis, A. Pressurized fluidized bed combustion (PFBC) combined cycle systems. In Combined Cycle Systems for Near-Zero Emission Power Generation; Elsevier: Amsterdam, The Netherlands, 2012; pp. $220-233$.

4. Chen, X.; Fu, Q.; Chang, C.P. What are the shocks of climate change on clean energy investment: A diversified exploration. Energy Econ. 2021, 95, 105136. [CrossRef]

5. Atsu, F.; Adams, S. Energy consumption, finance, and climate change: Does policy uncertainty matter? Econ. Anal. Policy 2021, 70, 490-501. [CrossRef]

6. Hambira, W.L.; Saarinen, J.; Moses, O. Climate change policy in a world of uncertainty: Changing environment, knowledge, and tourism in Botswana. Afr. Geogr. Rev. 2020, 39, 252-266. [CrossRef]

7. Sugiyama, M.; Fujimori, S.; Wada, K.; Weyant, J. Introduction to the special feature on energy scenarios for long-term climate change mitigation in Japan. Sustain. Sci. 2021, 16, 347-353. [CrossRef] 
8. Crecente, F.; Sarabia, M.; del Val, M.T. Climate change policy and entrepreneurial opportunities. Technol. Forecast. Soc. Chang. 2021, 163, 120446. [CrossRef]

9. Popczyk, J. Transformacja Energetyczna TETIP (Transformacja Energetyki w Trybie Innowacji Przełomowej) do Elektroprosumeryzmu Wehikułem do Przyszłości tu i Teraz. Available online: https://ppte2050.pl/platforman/bzppte/ static/uploads/artyku\%C5\%82\%20ze \%20statusem \%20artyku\%C5\%82u\%20S\%C5\%82ownika\%20encyklopedycznego \%20 Elektroprosumeryzmu\%20na\%20PPTE2050.\%20Jan\%20Popczyk.pdf (accessed on 12 July 2021).

10. Adams, S.; Adedoyin, F.; Olaniran, E.; Bekun, F.V. Energy consumption, economic policy uncertainty and carbon emissions; causality evidence from resource rich economies. Econ. Anal. Policy 2020, 68, 179-190. [CrossRef]

11. Bizon, N.; Oproescu, M.; Raceanu, M. Efficient energy control strategies for a standalone renewable/fuel cell hybrid power source. Energy Convers. Manag. 2015, 90, 93-110. [CrossRef]

12. Junne, T.; Simon, S.; Buchgeister, J.; Saiger, M.; Baumann, M.; Haase, M.; Wulf, C.; Naegler, T. Environmental sustainability assessment of multi-sectoral energy transformation pathways: Methodological approach and case study for Germany. Sustainability 2020, 12, 8225. [CrossRef]

13. Ward, S.; Butler, D.; Memon, F.A. Benchmarking energy consumption and $\mathrm{CO}_{2}$ emissions from rainwater-harvesting systems: An improved method by proxy. Water Environ. J. 2012, 26, 184-190. [CrossRef]

14. Chung, W. Review of building energy-use performance benchmarking methodologies. Appl. Energy 2011, 88, 1470-1479. [CrossRef]

15. Eichhammer, W.; Köwener, D.; Gruber, E. Energy efficiency benchmarking. In Policy Modeling for Industrial Energy Use; Engineering Economic Technology Analysis: Seoul, Korea, 2003; pp. 67-78.

16. Sontag, B.; Hirzel, S.; Bender, O.; Kloos, H.; Laubach, M.; Wallkötter, R.; Rohde, C. Energy-Benchmarking within Companies: Insights from Benchmarking Practice. 2014, pp. 637-646. Available online: https://www.researchgate.net/profile/ClemensRohde/publication/264255226_Energy-benchmarking_within_companies_insights_from_benchmarking_practice/links/53d6 321f0cf220632f3d8d3d/Energy-benchmarking-within-companies-insights-from-benchmarking-practice.pdf (accessed on 20 July 2021).

17. Xu, L.; Fuss, M.; Poganietz, W.-R.; Jochem, P.; Schreiber, S.; Zoephel, C.; Brown, N. An Environmental Assessment Framework for Energy System Analysis (EAFESA): The method and its application to the European energy system transformation. J. Clean. Prod. 2020, 243, 118614. [CrossRef]

18. Das, B.K.; Hasan, M. Optimal sizing of a stand-alone hybrid system for electric and thermal loads using excess energy and waste heat. Energy 2021, 214, 119036. [CrossRef]

19. Coronavirus. The World Economy at Risk. OECD Economic Outlook, Interim Report March 2020. Available online: https: //www.oecd-ilibrary.org/economics/oecd-economic-outlook/volume-2019/issue-2_7969896b-en (accessed on 12 July 2021).

20. The Polish Institute of International Affairs. The Great Lockdown: Impact of the COVID-19 Pandemic on the Global Economy. Available online: https://www.pism.pl/publications/The_Great_Lockdown_Impact_of_the_COVID19_Pandemic_on_the_ Global_Economy (accessed on 12 July 2021).

21. OECD. Economic Outlook, May 2021. Available online: https://www.oecd.org/economic-outlook/ (accessed on 12 July 2021).

22. OECD. OECD Economic Outlook, Interim Report March 2020; OECD Publishing: Paris, France, 2020. [CrossRef]

23. Kooronawirus, Raport Specjalny, Polska Gospodarka Podnosi się po Pandemii. Available online: https://www.money.pl/ gospodarka/polska-gospodarka-podnosi-sie-po-pandemii-boom-potrwa-ale-zaplacimy-za-niego-inflacja-6658604993018400 a.html (accessed on 12 July 2021).

24. Institute of Central Europe. Central European Economies: Different Faces of the COVID-19 Pandemic. Available online: https:/ / ies.lublin.pl/en/ (accessed on 12 July 2021).

25. Langsdorf, S. EU Energy Policy: From the ECSC to the Energy Roadmap 2050; Green European Foundation: Brussels, Belgium, 2011.

26. Dupont, C.; Oberthür, S. Insufficient climate policy integration in EU energy policy: The importance of the long-term perspective. J. Contemp. Eur. Res. 2012, 8, 2.

27. Repetto, R.; Austin, D. The Costs of Climate Protection; World Resources Institute: Washington, DC, USA, 1997.

28. Benz, E.; Trück, S. $\mathrm{CO}_{2}$ emission allowances trading in Europe-Specifying a new class of assets. Probl. Perspect. Manag. 2006, 4 , 30-40.

29. Rayner, T.; Jordan, A. Climate Change Policy in the European Union. In Oxford Research Encyclopedia of Climate Science; Oxford University Press: Oxford, UK, 2016.

30. Murphy, P.; Crosson, P.; O’Brien, D.; Schulte, R.P.O. The Carbon Navigator: A decision support tool to reduce greenhouse gas emissions from livestock production systems. Animal 2013, 7, 427-436. [CrossRef]

31. Bocquillon, P.; Maltby, T. EU energy policy integration as embedded intergovernmentalism: The case of Energy Union governance. J. Eur. Integr. 2020, 42, 39-57. [CrossRef]

32. Erdmenger, C.; Lehmann, H.; Müschen, K.; Tambke, J.; Mayr, S.; Kuhnhenn, K. A climate protection strategy for Germany-40\% reduction of $\mathrm{CO}_{2}$ emissions by 2020 compared to 1990. Energy Policy 2009, 37, 158-165. [CrossRef]

33. Capros, P.; Kannavou, M.; Evangelopoulou, S.; Petropoulos, A.; Siskos, P.; Tasios, N.; DeVita, A. Outlook of the EU energy system up to 2050: The case of scenarios prepared for European Commission's "clean energy for all Europeans" package using the PRIMES model. Energy Strategy Rev. 2018, 22, 255-263. [CrossRef] 
34. Sencar, M.; Pozeb, V.; Krope, T. Development of EU (European Union) energy market agenda and security of supply. Energy 2014, 77, 117-124. [CrossRef]

35. Montanarella, L.; Panagos, P. The relevance of sustainable soil management within the European Green Deal. Land Use Policy 2021, 100, 104950. [CrossRef]

36. Bertoldi, P.; Mosconi, R. Do energy efficiency policies save energy? A new approach based on energy policy indicators (in the EU Member States). Energy Policy 2020, 139, 111320. [CrossRef]

37. Peeters, M.; Stallworthy, M.; de Larragán, J.D.C. (Eds.) Climate Law in EU Member States: Towards National Legislation for Climate Protection; Edward Elgar Publishing: Cheltenham, UK, 2012.

38. Keesen, A.M. Adaptation to climate change in European water law and policy. Utrecht Law Rev. 2012, 8, 38. [CrossRef]

39. Agreement, P. Paris agreement. In Report of the Conference of the Parties to the United Nations Framework Convention on Climate Change; 21st Session; Springer: Paris, France, 2015; Volume 4, p. 2017.

40. Hellman, H.P.; Koivisto, M.; Lehtonen, M. Photovoltaic power generation hourly modelling. In Proceedings of the 2014 15th International Scientific Conference on Electric Power Engineering (EPE), Brno-Bystrc, Czech Republic, 12-14 May 2014; pp. 269-272.

41. Open Government Department of Energy. Available online: https://www.energy.gov/general/energy (accessed on 12 July 2021).

42. Sahu, A.; Yadav, N.; Sudhakar, K. Floating photovoltaic power plant: A review. Renew. Sustain. Energy Rev. 2016, 66, 815-824. [CrossRef]

43. Rynek Elektryczny. Energia Elektryczna ze źrodeł Odnawialnych. Available online: https:/ /www.rynekelektryczny.pl/energiaelektryczna-ze-zrodel-odnawialnych/ (accessed on 12 July 2021).

44. Ministry of Climate, Information and Recomendiaton. Available online: https:/ /www.gov.pl/web/climate (accessed on 12 July 2021).

45. Rynek Energetyczny, Moc Zainstalowana w Polsce. Available online: https://www.rynekelektryczny.pl/moc-zainstalowanaoze-w-polsce/ (accessed on 12 July 2021).

46. Polskie Sieci Elektroenergetyczne. Polskie Sieci Elektroenergetyczne, Raporty Roczne z Funkcjonowania KSE. Available online: https:/ / www.pse.pl/web / pse-eng (accessed on 12 July 2021).

47. Fraunhofer Institute for Solar Energy Systems, ISE. Available online: https://www.ise.fraunhofer.de/en/press-media/news/20 20/public--net-electricity-generation-in-germany-2020-share-from-renewables-exceeds-50-percent.html (accessed on 12 July 2021).

48. Overland, I. EU climate and energy policy: New challenges for old energy suppliers. In New Political Economy of Energy in Europe; Palgrave Macmillan; Springer: Cham, Switzerland, 2019; pp. 73-102.

49. Jaraitė, J.; Kažukauskas, A. The profitability of electricity generating firms and policies promoting renewable energy. Energy Econ. 2013, 40, 858-865. [CrossRef]

50. Energy Production Source in Germany in 2019 and 2020. Available online: https://www.statista.com/statistics/583155/energyproduction-energy-source-germany/ (accessed on 12 July 2021).

51. Gawel, E.; Lehmann, P.; Korte, K.; Strunz, S.; Bovet, J.; Köck, W.; Massier, P.; Löschel, A.; Schober, D.; Ohlhorst, D.; et al. The future of the energy transition in Germany. Energy Sustain. Soc. 2014, 4, 15. [CrossRef]

52. Balussou, D. An Analysis of Current and Future Electricity Production from Biogas in Germany; Deutsch-Französisches Institut für Umweltforschung (DFIU): Karlsruhe, Germany, 2018.

53. Pehnt, M.; Oeser, M.; Swider, D.J. Consequential environmental system analysis of expected offshore wind electricity production in Germany. Energy 2008, 33, 747-759. [CrossRef]

54. Gough, I.; Meadowcroft, J.; Dryzek, J.; Gerhards, J.; Lengfeld, H.; Markandya, A.; Ortiz, R. JESP symposium: Climate change and social policy. J. Eur. Soc. Policy 2008, 18, 325-344. [CrossRef]

55. Gardiner, S.M. Ethics and global climate change. Ethics 2004, 114, 555-600. [CrossRef]

56. Risbey, J.S. The new climate discourse: Alarmist or alarming? Glob. Environ. Chang. 2008, 18, 26-37. [CrossRef]

57. European Commission, Eurostat. Available online: https:/ / ec.europa.eu/eurostat/web/energy/data/main-tables (accessed on 12 July 2021).

58. Renewable Energy Policy Database and Support, Legal Sources on Renewable Energy. Available online: http://www.res-legal. eu/search-by-country/poland/ (accessed on 12 July 2021).

59. Change, A.D.C.; Blair, T.; Pachauri, R.K.; Pachauri, R. Avoiding Dangerous Climate Change; United States of America by Cambridge University Press: New York, NY, USA, 2006.

60. Renewable Energy Statistics—Statistics Explained. Available online: https:/ / ec.europa.eu/eurostat/statistics-explained/index. php?title=Renewable_energy_statistics (accessed on 12 July 2021).

61. Key World Energy Statistics 2020. Available online: https:/ / www.iea.org/reports/key-world-energy-statistics-2020 (accessed on 12 July 2021).

62. Energy Transition. The German Energiewende. Available online: http://kigeit.org.pl/FTP/PRCIP/Literatura/018\%20GermanEnergy-Transition_pl\%202014.pdf (accessed on 19 July 2021).

63. Chaisse, J. Renewables Re-energized? The Internationalization of Green Energy Investment Rules and Disputes. J. World Energy Law Bus. 2016, 9, 269-281. [CrossRef] 
64. Petersmann, E.U. Human Rights in International Investment Law and Adjudication: Legal Methodology Questions. In Handbook of International Investment Law and Policy; Chaisse, J., Choukroune, L., Jusoh, S., Eds.; Library Open Science Team; Springer: Singapore, 2020; pp. 1-27.

65. Xu, Q. The Challenges of Water Governance (and Privatization) in China; Normative Traps, Gaps, and Prospects. Ga. J. Int'l Comp. Law 2018, 47, 47. Available online: https:/ /digitalcommons.law.uga.edu/gjicl/vol47/iss1/4 (accessed on 16 July 2021).

66. Knutel, B.; Pierzyńska, A.; Dębowski, M.; Bukowski, P.; Dyjakon, A. Assessment of energy storage from photovoltaic installations in poland using batteries or hydrogen. Energies 2020, 13, 4023. [CrossRef]

67. Eurostat. Statistics Explained-European Commission. Available online: https://ec.europa.eu/eurostat/statistics-explained/ index.php?title=EU_imports_of_energy_products_-_recent_developments (accessed on 12 July 2021).

68. Instytut Energetyki Odnawialnej (EC BREC IEO), Progonoza cen Energii. Available online: https://ieo.pl/pl/projekty/prognozacen-energii (accessed on 23 July 2021).

69. Annual Energy Outlook 2021. Available online: https:/ / www.eia.gov/outlooks/aeo/tables_ref.php (accessed on 12 July 2021).

70. Eurostat. International Statistics, International Comparisons. Available online: https://stat.gov.pl/en/international-statistics/ international-comparisons / data-visualisation/ (accessed on 13 July 2021).

71. Eurostat. Electricity_Production. Available online: https://ec.europa.eu/eurostat/statistics-explained/index.php?title= Electricity_production (accessed on 14 July 2021).

72. European Commision. Design and Optimisation of Energy Flexible Industrial Processes. Available online: https://ec.europa.eu/ info/funding-tenders/opportunities/portal/screen/opportunities/topic-details/horizon-cl4-2021-twin-transition-01-21 (accessed on 12 July 2021).

73. Eurostat. National Accounts and GPD. Available online: https://ec.europa.eu/eurostat/statistics-explained/index.php?title= National_accounts_and_GDP (accessed on 15 July 2021).

74. Eurostat. Electricity Production, Consumption and Market Overvie. Available online: https://ec.europa.eu/eurostat/statisticsexplained/index.php?title=Electricity_production,_consumption_and_market_overview (accessed on 12 July 2021).

75. Eurostat. Consistency and Balance of Payments Statistics. Available online: https://ec.europa.eu/eurostat/statistics-explained/ index.php?title=consistency_and_balance_of_payments_statistics (accessed on 12 July 2021).

76. Haug, N.; Geyrhofer, L.; Londei, A.; Dervic, E.; Desvars-Larrive, A.; Loreto, V. Ranking the effectiveness of worldwide COVID-19 government interventions. Nat. Hum. Behav. 2020, 4, 1303-1312. [CrossRef] [PubMed]

77. Zbiorcze Informacje Dotyczace Energii Elektrycznej. Available online: https://www.ure.gov.pl/pl/urzad/informacjeogolne/publikacje/raport-wytwarzanie-ener/8832, Raport-zbiorcze-informacje-dotyczace-wytwarzania-energii-elektrycznejz-odnawial.html (accessed on 12 July 2021).

78. Ciesielska-Maciagowska, D.; Klimczak, D.; Skrzek-Lubasińska, M. Central and Eastern European $\mathrm{CO}_{2}$ Market-Challenges of Emissions Trading for nergy Companies. Energies 2021, 14, 1051. [CrossRef]

79. Mittelviefhaus, M.; Pareschi, G.; Allan, J.; Georges, G.; Boulouchos, K. Optimal investment and scheduling of residential multienergy systems including electric mobility: A cost-effective approach to climate change mitigation. Appl. Energy 2021, $301,117445$. [CrossRef]

80. Kang, J.N.; Wei, Y.M.; Liu, L.C.; Han, R.; Yu, B.Y.; Wang, J.W. Energy systems for climate change mitigation: A systematic review. Appl. Energy 2020, 263, 114602. [CrossRef]

81. Zhang, C.; Zhou, K.; Yang, S.; Shao, Z. On electricity consumption and economic growth in China. Renew. Sustain. Energy Rev. 2017, 76, 353-368. [CrossRef]

82. Li, C.; Wang, N.; Zhang, H.; Liu, Q.; Chai, Y.; Shen, X.; Yang, Z.; Yang, Y. Environmental impact evaluation of distributed renewable energy system based on life cycle assessment and fuzzy rough sets. Energies 2019, 12, 4214. [CrossRef]

83. Yang, Y.; Li, C.; Wang, N.; Yang, Z. Progress and prospects of innovative coal-fired power plants within the energy internet. Glob. Energy Interconnect. 2019, 2, 160-179. [CrossRef]

84. Kharlamova, G.; Nate, S.; Chernyak, O. Renewable energy and security for Ukraine: Challenge or smart way. J. Int. Stud. 2016, 9, 88-115. [CrossRef]

85. Available online: https://china.lbl.gov/publications/identifying-driving-factors-energy (accessed on 23 July 2021).

86. Strefa Inwestorów. Available online: https://strefainwestorow.pl/artykuly/oze/20210118/odnawialne-zrodla-energii-prognozy (accessed on 12 July 2021).

87. National Energy and Climate Plan. Available online: https://ec.europa.eu/clima/policies/strategies/2030_pl (accessed on 13 July 2021).

88. Forsal, Raporty Specjalne. Available online: https://forsal.pl/gospodarka/inwestycje/artykuly /8186862,polska-awansowala-wrankingu-atrakcyjnych-krajow-dla-inwestycji-w-oze.html (accessed on 17 July 2021).

89. Raport Prezesa URE za 2020 rok (Podstawa Prawna: Art. 17 Ustawy o Odnawialnych Źródłach Energii) Warszawa, Kwiecień; Biuletyn Informacji Publicznej; Urząd Regulacji Energetyki: Warszawa, Poland, 2020.

90. Piwowar, A.; Dzikuć, M. Development of renewable energy sources in the context of threats resulting from low-altitude emissions in rural areas in Poland: A review. Energies 2019, 12, 3558. [CrossRef]

91. Henning, H.M.; Palzer, A. What Will the Energy Transformation Cost? Pathways for Transforming the German Energy System by 2050; Fraunhofer Institute for Solar Energy Systems ISE: Freiburg, Germany, 2015. 
92. Energy Regulatory Office. Available online: https:/ / www.ure.gov.pl/en (accessed on 18 July 2021).

93. Centrum Informacji o Rynku Energii. Available online: https:/ /www.cire.pl/artykuly/serwis-informacyjny-cire-24/187546rzad-planuje-oplate-koncesyjna-w-dla-magazynow-energii-i-zmiane-oplaty-dla-offshore (accessed on 21 July 2021). 